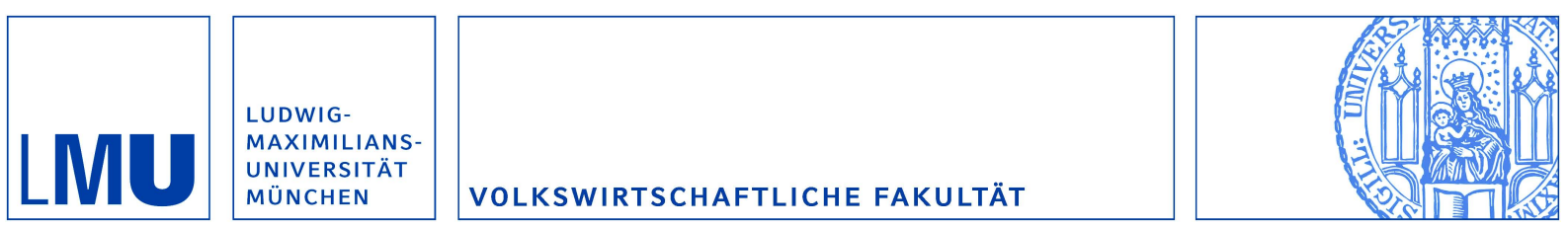

Buchheim, Lukas und Watzinger, Martin:

The Employment Effects of Countercyclical Infrastructure Investments

Munich Discussion Paper No. 2017-6

Department of Economics

University of Munich

Volkswirtschaftliche Fakultä†

Ludwig-Maximilians-Universitä† München

Online at https://doi.org/10.5282/ubm/epub.34877 


\title{
The Employment Effects of Countercyclical Infrastructure Investments
}

\author{
Lukas Buchheim Martin Watzinger*
}

February 26, 2017

\begin{abstract}
We estimate the causal impact of a sizable German infrastructure investment program on employment at the county level. The program focused on improving the energy efficiency of school buildings, making it possible to use the number of schools as an instrument for investments. We find that the program was effective, creating one job for one year for each $€ 25$ '000 of investments. The employment gains reached their peak after nine months and dropped to zero quickly after the program's completion. The reductions in unemployment amounted to two-thirds of the job creation, and employment grew predominately in the construction and non-tradable industries.
\end{abstract}

Keywords: Infrastructure Investments, Job Creation, Employment Dynamics, Countercyclical Fiscal Policy

JEL Classification: E24, E62, H72, J23

\footnotetext{
*Department of Economics, LMU Munich, Geschwister-Scholl-Platz 1, 80539 Munich, Germany; Lukas Buchheim: lukas.buchheim@econ.lmu.de (corresponing author). For helpful comments, we thank Daron Acemoglu, Isaiah Andrews, Josh Angrist, David Autor, Anna Gumpert, Xavier Jaravel, Christian Merkl, Johannes Schmieder, Ludwig Straub, Uwe Sunde, Fabian Waldinger, Joachim Winter, and seminar participants at M.I.T., Bayreuth, Nuremberg, and Würzburg, the SED Meeting 2015, the 2015 ifo Conference on "Macroeconomics and Survey Data", and the Labor Seminar in Lech. We also thank Nathan Hauke from the Leuphana University for the thoughtful and successful replication of a preliminary version of this paper. Martin Watzinger gratefully acknowledges financial support from the Deutsche Forschungsgemeinschaft through CRC TRR 190. Parts of this paper were written while Lukas Buchheim was visiting M.I.T.; he thanks the members of the Department of Economics for their hospitality.
} 


\section{Introduction}

Infrastructure investment is an important tool of fiscal policy that has been used heavily in recent years. Infrastructure investment programs were major parts of the stimulus programs that were enacted in the wake of the Great Recession to bolster economic conditions (OECD, 2009). More recently, there have been calls for governments to capitalize on the low borrowing costs by increasing their investments in the infrastructure to reduce the output gap when output is below its potential (IMF, 2014). Despite their widespread use, it is debated whether infrastructure investments constitute an effective tool of countercyclical fiscal policy. Proponents argue that public investments directly create jobs and possibly pay a double dividend by increasing the future growth potential. In contrast, opponents worry that job creation via public investments crowds out private sector employment and that the long planning periods of investment projects prevent putting people to work quickly in times of economic crisis.

Do countercyclical infrastructure investments create jobs quickly and cost-effectively? In this paper we answer this question for a sizable infrastructure investment program of 0.63 percent of the GDP (€15.7 billion) that was a major component of the German stimulus package during the Great Recession. Using cross-sectional data on investments at the county level, we estimate the causal dynamic effect of investments on aggregate and industry specific employment as well as on unemployment.

The unique set-up of the German investment program allows us to address three key challenges for the evaluation of countercyclical fiscal policy in general and infrastructuexitrre investments in particular. The first challenge is that stimulus investment programs are by construction endogenous to economic conditions. In particular, many stimulus packages - including the American Recovery and Reinvestment Act (ARRA) and the German investment program studied here - share the characteristic that states have a high level of discretion in distributing federal funds to regions. As a consequence states potentially channeled funds towards those regions that were (or were expected to be) hit the hardest by the recession. We address this endogeneity problem by exploiting the legal structure of the stimulus bill. The bill prescribed that 65 percent of funds had to be spent on investments in the educational infrastructure, in particular on improving the energy efficiency of existing buildings. ${ }^{1}$ This implies that the local

\footnotetext{
${ }^{1}$ The remaining 35 percent were earmarked for investments in the general local infrastructure like the renovation of public buildings or the construction of broadband infrastructure. In general, there were detailed conditions for projects to be financed via stimulus funds, because the German
} 
scope for investments was closely linked to the historically predetermined number of schools. Since the number of schools is a persistent stock variable and thus unrelated to the magnitude of the recession in a county, it constitutes an ideal instrument for local investments.

The second challenge is that the evaluation of stimulus investment programs is frequently inhibited by the lack of identifying variation in the data. Stimulus programs affect the entire economy so that it is difficult to separate the effect of stimulus spending from contemporaneous shocks using longitudinal data only (Parker, 2011). Meaningful cross-sectional variation in spending on infrastructure, in turn, is often confined to the state level due to the large scale of most infrastructure investment programs (e.g., highway construction). For the investment program studied here, in contrast, there is ample and meaningful variation in investments across the 402 German counties that can be used to identify the effect of infrastructure investments on local labor markets. This is due to the requirement of the stimulus bill that at least 70 percent of funds had to be used for financing projects at the municipal or county level.

The third challenge is that public investments often have long implementation lags. As a consequence, anticipation effects make it difficult to identify the correct time window during which the effect of the investments on the economy should be observed. However, if the empirical analyses are conducted for the wrong time window, the results may be downward biased (see, e.g., Leeper et al., 2010; Ramey, 2011b; Leduc and Wilson, 2013). In this paper we can estimate the total effects of the investment program, because it was implemented following a strict and well-defined schedule. The stimulus bill took effect in January 2009, projects had to be underway by the end of 2010, and all the funds had to be spent by the end of 2011. Hence, there is little room for anticipation effects or implementation lags so that the main employment effects of the program are expected to be observed between 2009 and the end of 2011.

Results We find that infrastructure investments increased employment cost-effectively. The instrumental variable (IV) estimates imply that additional investments of €100'000 led to a gain of four job years. This point estimate corresponds to costs per job year of $€ 25 ’ 000$ (equivalent to $\$ 34 ' 200$ according to the average euro-dollar exchange rate

constitution heavily restricts the federal government's means to implement regional policies. The detailed funding requirements thus ensured that constitutional restrictions were met, and investments at the local level - the main goal of the program - were made possible. For details regarding the program (called Zukunftsinvestitionsgesetz), see Section 2. 
between Q1 2009 and Q4 2011). Compared with the yearly union wages in construction - the primary target industry - of at least €30'000, this implies a substantial local "wage multiplier," the ratio between the costs per job year and the wage, of 1.2.

The infrastructure investment program also had a quick impact. The effects built up during the year 2010, indicating an implementation lag of three quarters, which seems reasonable given that the projects had to be planned and approved before implementation. This finding alleviates the common concern that the implementation of investment programs takes such a long time that they are an ill-suited policy tool for a downturn when quick reactions are required (Becker, 2009; Summers, 2008). Moreover, the employment effects estimated via IV drop sharply in the first quarter of 2012 , exactly at the time when all the infrastructure projects had to be completed. The dynamic pattern of employment gains is thus precisely as expected given the design of the program.

The employment gains are accompanied by a drop in unemployment of two to three person-years per €100'000 of investments, one-half to three-quarters of the employment gains. This result suggests that infrastructure investments increase the demand for workers with a high likelihood of being unemployed, in contrast to the concern voiced for example by Becker (2009) and Glaeser (2016), that investments predominantly increase the demand for specialists who are already in short supply.

Finally, the data supports the hypothesis that the infrastructure investments predominantly increased employment in construction related industries as well as nontradable industries like retail and hospitality. The employment effects originate exclusively from these industries with both contributing about half of the total employment gains.

The identifying assumption of the IV strategy is that counties with different numbers of schools would have followed the same employment paths absent the stimulus program. This assumption is untestable. However, the number of schools in Germany is very persistent over time and hence unlikely to be correlated with economic conditions in the short or medium run. This is because the schools build after World War II and during the population boom of the 1960s and 1970s are sufficient to meet the current demand in a time of an aging population so that the number of public buildings has changed little since then. In fact, the number of schools in 1995 is an almost perfect predictor of today's number of schools, and our results are insensitive to the year in which the number of schools is measured. Also, we show that the number of jobs is 
unrelated to the number of schools in the two years before the program, supporting the credibility of the identifying assumption.

The results are unaffected by a variety of robustness and sensitivity checks. For example, we rule out the potential concern that our estimates of the investment program's effectiveness are distorted by sizable regional spillovers across neighboring counties. We also control for the number of short-time workers - the extension of subsidized short-time work was another main component of the German stimulus package - and different indicators that may be correlated both with the employment outcomes and with the number of schools (like the educational structure of the workforce) and show that this leaves the conclusions unchanged.

Contribution This study is the first to show that infrastructure investments can be a cost-effective way to quickly create jobs in a downturn so that infrastructure investments can be a suitable tool to counteract a beginning recession. As such, our work is related to a small recent literature that uses cross-sectional data together with plausible identification strategies to estimate the economic consequences of infrastructure investments. $^{2}$ For normal economic times, Acconcia et al. (2014) show that sudden contractions of public works due to Mafia infiltration of city councils in Italy led to immediate reductions in output with a multiplier of $1.5-1.9 .^{3}$ Furthermore, there is mixed evidence regarding the local economic effects of highway construction. Leduc and Wilson (2013) use institutional details of the distribution of highway grants among states in the U.S. to identify unanticipated investment shocks. The local multiplier from

\footnotetext{
${ }^{2}$ The bulk of the evidence concerning the effect of public investment on income and employment comes from vector auto regression (VAR) approaches and points towards multipliers around one (e.g., Pereira, 2000; Perotti, 2004; Kamps, 2005; see also Leduc and Wilson, 2014, for a recent survey). This literature builds on the structural VAR approach of estimating the multiplier of aggregate government spending pioneered by Blanchard and Perotti (2002). Auerbach and Gorodnichenko (2012) and Owyang et al. (2013) explore whether the aggregate spending multiplier differs between recessions and expansions, a topic that is particularly relevant when discussing countercyclical policy. Ramey (2011a) provides a recent review of the literature for the effects of aggregate spending in the U.S.; Beetsma and Giuliodori (2011) summarize the results for Europe. The benefit of the VAR studies is that they estimate, in principle, the aggregate effect of fiscal investments, taking general equilibrium effects at the national level into account. In panel data approaches like ours, in contrast, the time fixed effects typically difference out all effects operating on the national level. However, the benefit of estimating the aggregate effect from time series data comes at the cost of strong timing assumptions for identification. See Nakamura and Steinsson (2014), Farhi and Werning (2016), and Dupor (2016) for details on the connection of the aggregate and the local multiplier.

${ }^{3}$ Also for Italy, Porcelli and Trezzi (2014) find much smaller multipliers from reconstruction grants following an earthquake. However, local spillovers may be an issue, as "treated" and "untreated" municipalities are both within a radius of about $50 \mathrm{~km}$ from the earthquake's epicenter.
} 
these shocks may be as high as 8 at its peak, but with a lag of six to eight years after the shock. These lags may also account for the findings of Garin (2016), who uses a selection-on-observables strategy and finds only a small immediate effects of the ARRA highway construction grants on local markets. ${ }^{4}$ Another way to reconcile the latter findings with the evidence presented in this paper is that investment projects requiring relatively standard types of labor, like the building renovations studied here, have a more direct impact on local markets than projects requiring specialized firms, which operate nationwide, like highway construction. In this case, the composition of stimulus programs would be of first order importance for their effectiveness.

By isolating the effect of one particular stimulus measure, this study also adds to the literature evaluating the effectiveness of stimulus programs in general. A number of papers estimated the combined effects of the different stimulus measures (e.g., transfers to individuals, financing of public employment, or infrastructure investments) included in the ARRA (Feyrer and Sacerdote, 2011; Chodorow-Reich et al., 2012; Wilson, 2012; Conley and Dupor, 2013; Dube et al., 2014; Dupor and McCrory, 2015; Dupor and Mehkari, 2016)..$^{5}$ The costs per job year for the aggregate stimulus reported in this literature vary widely between \$26’000 (Chodorow-Reich et al., 2012) and \$202’000 (Conley and Dupor, 2013); our estimates are at the lower end of this range. One possible reason for the comparably low estimates is that infrastructure investments are a particularly effective stimulus measure. Another possible reason is that we consider the full employment dynamics of the investment program - from the beginning of 2009 to the end of 2011 - while the earlier studies of the ARRA focus on the period from early 2009 to mid or late 2010. Indeed, the bulk of the employment gains that we find comes from the second half of the program's time window, consistent with Dupor and McCrory (2015) showing that a large fraction of the ARRA gains accrued in 2011 and

\footnotetext{
${ }^{4}$ Leduc and Wilson (2015) focus on documenting that the ARRA's federal highway construction grants did not crowd out of investments by the states, but also estimate relatively high costs per job year of $\$ 500$ '000 within the road construction sector. However, this estimate does not account for spillover effects into other parts of the economy. In contrast, Feyrer and Sacerdote (2011), who mainly measure the overall effectiveness of the ARRA, provide a single but noisy estimate showing that the highway grants have been among the most effective measures of the ARRA in creating jobs.

${ }^{5}$ Other papers use disaggregate data to assess the local economic effects of total non-defense government spending in normal economic times. For the U.S., Shoag (2010) and Suárez Serrato and Wingender (2016) find costs per job year between $\$ 25^{\prime} 000$ and $\$ 35 ’ 000$ for total local government spending, wich are close to our estimates for countercyclical investments. Clemens and Miran (2012) find smaller effects. There is also evidence for the heterogeneity of the effectivenss of fiscal spending with respect to the underlying economic conditions both for Brazil (Corbi et al., 2014) and Germany (Buchheim et al., 2016). Fuchs-Schündeln and Hassan (2016) provide a review of the literature.
} 
Structure of the Paper The next section describes the German stimulus investment program. Section 3 briefly describes the data used, Section 4 presents the empirical model, and Section 5 outlines the identification strategy. In Section 6 we discuss the main results, the dynamic effects of stimulus investments on employment and unemployment. Section 6 also provides extensive robustness checks. The last section concludes.

\section{The German Stimulus Investment Program}

The investment program (called Zukunftsinvestitionsgesetz) was the major government spending measure within the two German stimulus packages enacted during the peak of the Great Recession. It stipulated investments of $€ 13.3$ billion into the general local infrastructure. Due to extensive co-financing of the states, €15.83 billion or 0.64 percent of the pre-crisis GDP (in 2008) was in fact spent. ${ }^{7}$

The aim of the investment program was to stimulate the economy at the local level by providing local governments with federal funds. However, because investments at the state level or below are within the authority of the states, the German Constitution severely limits the means of the federal government to finance local investments (Art. 104b Grundgesetz). Specifically, admissible local investment programs need to fulfill three requirements. First, the provision of investment funds to the states can only be temporary. Second, the type of investment projects to be financed must be specified by law. Third, the federal government can only provide transfers, so that the

\footnotetext{
${ }^{6}$ By finding sizable macroeconomic effects for infrastructure investments, this paper also adds to the research that studies the impact of other particular countercyclical policies. Dupor and Mehkari (2015) evaluate the effects of the Department of Education's grants within the ARRA, finding negligible effects of these short-lived grants on employment in the education sector. Parker et al. (2013) find that consumers spent between 50 and 90 percent of the tax rebates that they received during the beginning of the Great Recession. For the cash for clunkers program in the U.S., Mian and Sufi (2012) and Green et al. (2016) estimate that $\$ 2.85$ billion in subsidies caused an short lived demand increase (and a subsequent demand reversal) of 360'000 to 540'000 cars, but did not affect local employment.

${ }^{7}$ In addition, the stimulus packages contained two smaller investment programs providing $€ 6$ billion for investments at the federal level (mainly in the transportation infrastructure), reductions in taxes and social security contributions of $€ 66.2$ billion, and subsidies of $€ 9.4$ billion (mainly for a cash-forclunkers program). The package also contained direct labor market interventions such as an extension of the duration of short-time work benefits to workers of firms in temporary financial distress. See Bundesministerium für Wirtschaft und Technologie (2011) for details.
} 
decisions regarding which projects will receive funding is at the discretion of the state governments.

For these reasons, the stimulus bill (the Zukunftsinvestitionsgesetz as well as the accompanying implementation bill) entailed detailed requirements for projects to be financed via federal funds. Specifically, the bill mandated that 65 percent of funds were to be used for investments in the educational infrastructure. This first funding line authorized investments in (pre-)schools, universities, and research institutes with an emphasis on the energy-saving remodeling of existing buildings. The remaining 35 percent of funds had to be used for investments in the general public infrastructure, in particular hospitals, urban development, broadband infrastructure, and roadway noise mitigation. To reduce the fungibility of the funds, only "new and additional" projects could be financed. In practice this implied that projects that were already budgeted in a public account could not receive financing from the program. ${ }^{8}$

In addition to these restrictions on the types of investment projects, the bill required that projects were implemented locally. It mandated that 70 percent of the funds were to be spent on infrastructure investments at the county or municipal level. In fact, the majority of states, particularly the larger ones, spent more than 75 percent (with a maximum of 87.3 percent) of the funds locally (Bundesministerium der Finanzen, 2013b). The federal government also loosened the rules for public procurement to speed up the implementation of projects. According to the German Court of Auditors, this led to a substantial increase in the share of contracts awarded to local firms for the projects financed by the program (Bundesrechnungshof, 2012).

The federal government provided $€ 10$ billion for investments and distributed these funds among the states following a standard formulary allocation factor. The federal funds were matching grants financing at most 75 percent of the project costs; the remaining 25 percent of the funds (or more) had to be provided by the states or more regional layers of government (counties and municipalities). The latter contributed more than the required $€ 3.3$ billion so that the total spending equaled $€ 15.83$ billion. The final selection of the investment projects to be financed from these funds was at the discretion of the states. While the exact allocation mechanisms differed widely across states, most of them used a combination of the following three procedures: (i) the formulary allocation of funds to local layers of government (based on, e.g., the pop-

\footnotetext{
${ }^{8}$ In Appendix C.1 we demonstrate that the fungibility of the investment funds was indeed limited so that the crowding-out of other local public investments can be ruled out. If anything, there seems to have been crowding-in of local public investments.
} 
ulation, the number of school students, or the area), (ii) a state-wide selection among project proposals of regional layers of government, and (iii) the direct implementation of projects through the state government (Slansky, 2010).

The program was implemented swiftly. The first parliamentary hearings took place on January 12, 2009. The parliament passed the bill on March 5, and states had to report their implementation procedures to the federal government by May 30. Projects could receive financing from the program if they had been started on January 27, 2009, or later, and all projects had to be under way by the end of 2010. Projects had to be completed by the end of 2011, less than three years after the passage of the program. In fact, of the $€ 10$ billion in federal funds, for which we know the dynamics of spending over time, 12.6 percent were spent in 2009, 41.3 percent were spent in 2010, and the remaining 46.1 percent were spent in 2011 (Bundesministerium der Finanzen, 2011, 2012, 2013a).

\section{Data and Identifying Variation}

This section describes the main variables of interest with a focus on countercyclical investments, the independent variable, as well as the number of schools, the instrumental variable, for both of which we highlight the variation across German counties. Unless noted otherwise, all the variables are measured at the county level and normalized by the county's working-age population (between 15 and 65 years of age) in 2008 . This normalization facilitates the comparison of variables across counties. The data appendix (Appendix A) provides additional details.

\subsection{Employment and Unemployment}

The Federal Employment Agency (Bundesagentur für Arbeit) collects administrative data on employment and unemployment. The data is of single-digit precision and contains minimal sampling error. From this data we take the publicly available series on total employment and total unemployment at the county level for each quarter (measured on the last day of the quarter) for the years 2007 to 2013 and filter out county-specific seasonal fluctuation using the interaction of county and quarter-of-year fixed effects. ${ }^{9}$ The quarterly employment series counts every employed individual who

\footnotetext{
${ }^{9}$ The data thus includes the three years 2009-2011, during which the program was active as well as two years before and after the program.
} 
lives within a county and pays social security contributions, including part-time workers (as long as they earn more than €400 per month) but excluding the self-employed and public servants. The series also includes workers by age bands. The quarterly unemployment series contains every individual who lives within a county and receives unemployment benefits.

In addition, we obtained the quarterly series of employment, disaggregated by the three-digit industry code of the workers' employers, directly from the Federal Employment Agency. Due to major changes made to the industry classification in 2008, this data is available from 2008 onward.

\subsection{Countercyclical Investments}

The primary source for data on countercyclical investments is the complete, nationwide database of the $42^{\prime} 530$ projects financed by the program, which we obtained from the federal department of the treasury. This database exists because the stimulus bill required state governments to document that their usage of funds was in accordance with the legal requirements. As a consequence, the database contains the total investment in each project (summing up to €15.83 billion nationwide), the amount of federal funds used (a total of $€ 9.99$ billion revealing that nearly all the federal funds have been spent), and an indicator for the location where the project was conducted. ${ }^{10}$ Notably, there is no information on when the projects were implemented other than the requirement of the bill that all investments had to take place between March 2009 and the end of December 2011.

Based on the projects' locations, we aggregate the total investments at the county level. Given this, the identification of the effect of countercyclical investments on employment and unemployment rests on the cross-sectional variation in investments across counties within states. Figure 1 plots this geographic variation in investments. Counties are shaded according to their quintile in investments per capita relative to their state-specific means. Figure 1 shows that, even for the raw data at the state

\footnotetext{
${ }^{10} \mathrm{By}$ law, the states were also required to provide a short description of each project so that the appropriate usage of funds could be verified. The department of the treasury did not pass on this information. However, before receiving the complete project database from the federal government, we collected the latest available versions of the project databases from the state governments. While these databases are not entirely complete (they include 96 percent of projects and 95 percent of investments), they contain the project descriptions for most states. In Appendix B.1 we use these descriptions to verify that the number of schools predominantly predicts the number of school related projects as well as investments in schools.
} 
Figure 1: The Geographic Distribution of Countercyclical Investments

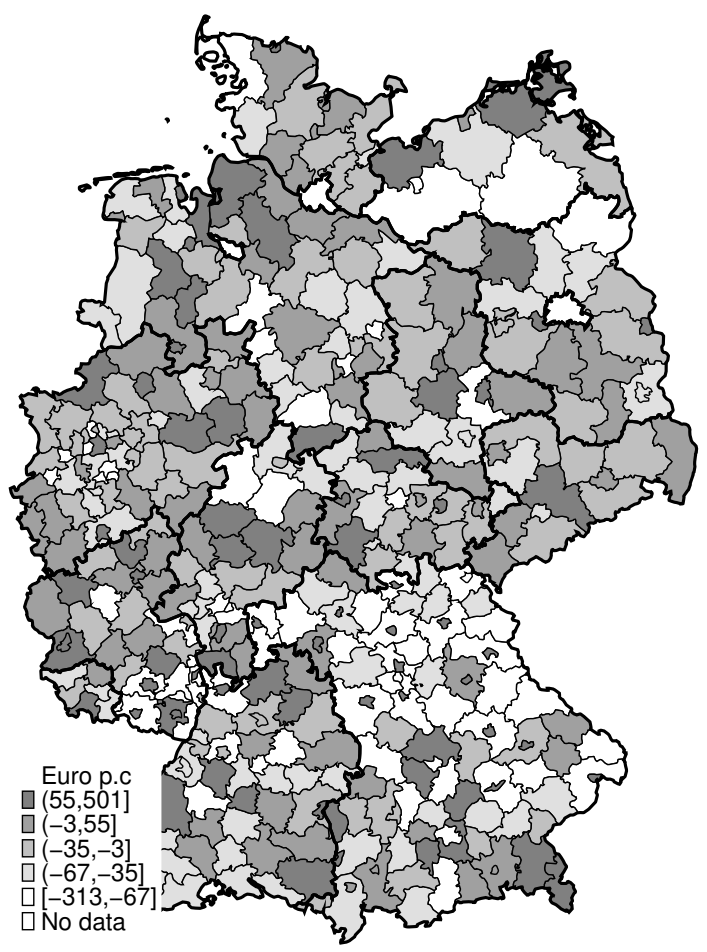

Notes. This map shows the geographic distribution of countercyclical investments per capita across counties in Germany. Investments are shown net of their state averages. The shading corresponds to the quintiles in investments; darker shading indicates larger investments.

level, there is ample variation in investments across counties without any apparent geographical clustering of regions with large or small investments. The inter-quintile range of investments is €122 per capita, which is substantial compared with the average investments of $€ 282$ per capita across Germany. For the mean county with a workingage population of about $127^{\prime} 000$ persons, the inter-quintile range corresponds to sizable differences in total investments of €15.5 million.

\subsection{Schools}

The substantial discretion of states in the allocation of funds creates the potential for a simultaneity problem, namely that states channeled funds into counties that were expected to be affected severely by the crisis. To alleviate this problem, we exploit the legal requirements of the stimulus bill and use the pre-crisis number of schools in a county, as measured in 2008, to instrument for countercyclical investments. 
Figure 2: The Distribution of Schools per Capita within States

(a) Primary and Secondary Schools

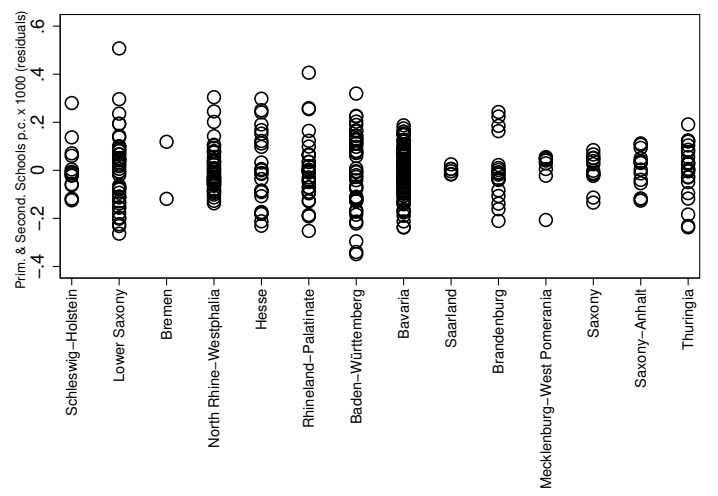

(b) Academic High Schools

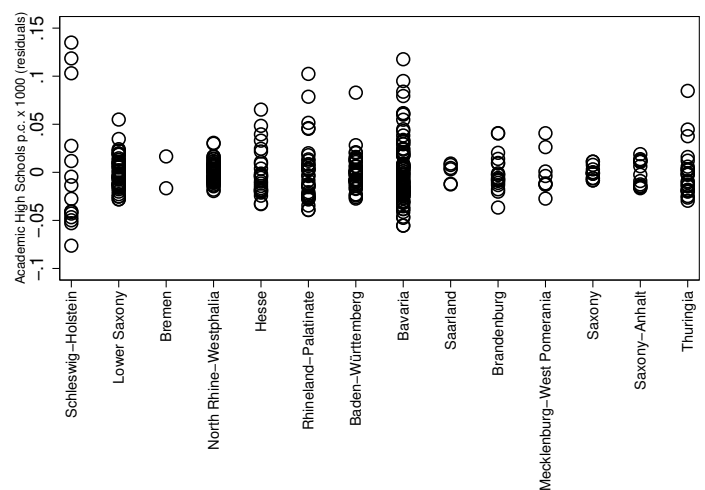

Notes. This figure shows the variation in Academic High Schools and Primary and Secondary Schools per 1000 individuals of working age across states. Each circle corresponds to one county and shows the number of schools net of its state-specific average.

The German Federal Statistical Office (Destatis) provides data on the number of schools at the county level separately for five major and five minor school types. These school types vary significantly in size. Because the size of a school determines the scope for energy-saving remodeling, we sort the ten school types into two categories according to their size. The first category, called "academic high schools," encompasses two types of secondary schools that award a degree (Abitur), which allows the pursuit of a college education. A school in this category has 788 students on average. The second category includes all the remaining school types, namely primary schools as well as secondary schools that offer degrees which are the precondition for vocational training. We call this category "primary and secondary schools." A school in the latter category has 196 students on average so that academic high schools are typically around four times as large as primary and secondary schools. ${ }^{11}$

Figure 2 displays the number of schools per 1000 individuals of working age within the German states. Each circle represents the number of schools within one county relative to their state-specific average. The number of schools varies considerably within states. The maximum difference between the county with the lowest and the county with the highest number of Primary and Secondary Schools per 1000 individuals equals

\footnotetext{
${ }^{11}$ Table 8 in Appendix A.2 provides additional information on the differences in school size across all the school types as well as on the classification of schools.
} 
at least 0.3 to 0.4 , which is sizable considering that the average is 0.55 . The average number of Academic High Schools per 1000 individuals is 0.07 so that the maximum difference of 0.05 to 0.1 is large as well.

\subsection{Control Variables}

The empirical analyses at the county level ensure that the number of observations is sufficiently high to control for a variety of potential confounding factors. In all the empirical analyses, we control for population density via an urbanization index. The index is published by the German Federal Office for Building and Regional Planning and classifies each county, based on its total population and population density, as either "very rural," "rural," "city," or "major city." In addition, we always control for the growth of the working-age population (between 16 and 65 years of age) given by the ratio of the current working-age population to the working-age population in 2008. The population data was obtained from the German Statistical Office. For brevity, detailed descriptions of all additional covariates are relegated to Appendix A.1. Unless noted otherwise, the variables were obtained either from the Federal Employment Agency (all the variables concerning employment, employment subsidies, or unemployment) or the German Statistical Office (the vast majority of the remaining variables).

\section{Empirical Model}

The goal of the empirical strategy is to assess both the dynamic employment response and the overall employment effect of the investment program. To this end, we use a generalized difference-in-differences (DiD) framework to estimate the investmentinduced employment gains, denoted $\beta_{t}$, for each quarter between Q1 2009 and Q4 2011. The employment gains are measured relative to Q4 2008, the last quarterly date before the (retroactive) start of the investment program in January 2009. This ensures that the estimated employment gains capture the possible anticipation effects as well as all the direct effects. The dynamic employment response is then described by the

sequence $\left\{\beta_{t}\right\}_{t=\mathrm{Q} 12009}^{\mathrm{Q} 42011}$ within the treatment period. The total number of job years created, in turn, is the sum of the quarterly employment differences $1 / 4 \cdot \sum_{t=\mathrm{Q} 12009}^{\mathrm{Q} 4} 2011$. 
The empirical model to estimate $\beta_{t}$ is

$$
\begin{aligned}
& \text { Employment p. } c_{c, t}=\sum_{t: t \neq \mathrm{Q} 42008} \beta_{t} \text { Investments p.c. } \cdot_{c} \times \text { Date }_{t}+\text { CountyF }_{c} \\
& +\sum_{t: t \neq \mathrm{Q} 42008} \text { Date }_{t} \times \text { CountyCharacteristics } \boldsymbol{c}_{\boldsymbol{c}} \boldsymbol{\Gamma}_{\boldsymbol{t}}+\psi \text { PopGrowt }_{c, t}+\varepsilon_{c, t},
\end{aligned}
$$

where the index $c$ denotes the county, $t$ denotes the date (measured in quarters), and "p.c." (for "per capita") in the variable name indicates that the variable is normalized by the county's working-age population measured in 2008. Investments are measured in $€ 100$ '000. ${ }^{12}$

To estimate the dynamic employment differences we interact the cross-sectional data on investments with date dummies (denoted Date $e_{t}$ ), a standard method for identifying the dynamic effect of an intervention in a DiD design (Angrist and Pischke, 2009). Since the employment differences are estimated relative to Q4 2008, estimating (1) delivers estimates of $\beta_{t}$ both for the dates after Q4 2008, when the effects of the investments should be observed, and for the dates before Q4 2008, for which $\beta_{t}$ should equal zero, since the investment program was neither active nor expected at that time. Estimating $\beta_{t}$ for dates before Q4 2008 thus allows us to test whether the (instrumented) investments were, in fact, unrelated to the employment dynamics before the program.

The set of control variables in (1) includes county fixed effects (denoted County $F E_{c}$ ) and date fixed effects for all state-urbanization strata (the urbanization strata are given by the values of the urbanization index). ${ }^{13}$ The date fixed effects on the state level are important to account for the link between the states' economic conditions and the federal transfers of investment funds via the formulary allocation factor, which includes tax income as one of its arguments. ${ }^{14}$ The date fixed effects for each urbanization

\footnotetext{
${ }^{12}$ In Appendix $\mathrm{C}$ we verify that two alternative empirical specifications deliver estimates similar to those from (1). In Appendix C.2, $\beta_{t}$ is estimated relative to all dates prior to Q1 2009, that is, relative to the average employment between Q1 2007 and Q4 2008. In Appendix C.3 we collapse (1) into a more parsimonious cross-sectional specification that allows us to estimate the job years created by the program but not the dynamics of the employment responses.

${ }^{13}$ We include date fixed effects along the dimensions of state $\times$ urbanization in equation (1) by adding the interactions of indicator variables for the states and indicator variables for the values of the urbanization index to the vector CountyCharacteristics ${ }_{\boldsymbol{c}}$.

${ }^{14}$ Another reason for the inclusion of state fixed effects is that states differ widely in their education policies, resulting in considerable differences in the public school system across states. Since the investments targeted the educational infrastructure, there may be a potential link between investments and employment dynamics at the state level. The time fixed effects on the state level account for
} 
category control for potential differences in the employment dynamics across urban and rural counties that may be correlated with urbanization-related differences in the existing infrastructure. Notably, the date fixed effects also eliminate all the employment differences due to policies at the state or federal level, including those that may dampen the effectiveness of the investment program, such as monetary policy or tax changes to maintain balanced budget requirements (see Nakamura and Steinsson, 2014, for an extensive discussion of this issue).

We control flexibly for three additional county characteristics that may be correlated both with employment outcomes and with infrastructure investments. First, employees with different levels of education may be affected differentially by the recession. They may also have differential demands for schools, which determine the scope for investments. For these reasons, the employment shares by education (with a college degree, with completed vocational training) are included in the set of control variables. Second, another plausible driver of the demand for schools is the schoolage population, which also determines the labor market inflow of young workers. We thus add the number of individuals between 6 and 18 years of age as a share of the working-age population to the set of covariates. Third, the numbers of hospitals and universities within the county, normalized by the working-age population, constitute two additional control variables. Hospitals and universities are more likely to be located in regional centers with potentially distinct employment dynamics. At the same time, they are determinants of the allocation of investment funds via two funding lines of the infrastructure program. All the variables just mentioned are included in the vector CountyCharacteristics $_{\boldsymbol{c}}$ with values as measured in the first quarter of $2008 .^{15}$

Finally, we control for population growth using the ratio of the working-age population at $t$ to the working-age population in 2008 (denoted PopGrowt $h_{c, t}$ ).

\section{$5 \quad$ Identification Strategy}

The main concern for identification is that the state governments used the investment funds to support those counties that they expected to be affected the worst by the recession. As state governments are likely to have better information regarding the trajectories of counties' economies than is captured by observable covariates, it is ques-

\footnotetext{
these differences as well.

${ }^{15}$ The county characteristics described here are the covariates used in the main empirical analyses. The robustness checks in Section 6.4 add additional variables to the empirical model.
} 
tionable whether this concern can be ruled out via controlling extensively for observable county characteristics. However, if governments redirect stimulus funds to counties that they expected to experience a weak labor market performance based on unobservable information, Investments $s_{c}$ and the error term $\varepsilon_{c, t}$ are negatively correlated (at least for $t \geq$ Q1 2009), and the OLS estimates of $\beta_{t}$ are biased towards zero.

We address this endogeneity problem using an IV strategy that exploits the legal requirements of the stimulus bill regarding which type of projects can receive financing. 65 percent of stimulus funds had to be used for investments in the local educational infrastructure, particularly for the energy-saving remodeling of existing buildings. The number of buildings of the educational infrastructure - typically schools - within a county thus determines, to a large extent, the scope for infrastructure investments. ${ }^{16}$ The empirical strategy to deal with the potential endogeneity problem just described is hence to use the number of schools in 2008 as an instrument for the infrastructure investments.

This section discusses the main assumptions of the IV strategy. The following subsection presents the first stage. Section 5.2 argues that the exclusion restriction is likely to be satisfied because the number of schools is strongly autocorrelated over long time horizons so that the number of schools does not react to the regional economic conditions in the short-run.

\subsection{Relevance and First Stage}

One main assumption of the IV strategy is that the instruments are relevant, that is, the number of schools is a strong predictor of infrastructure investments. Typically, the relevance of the instruments is tested using the first stage of the IV model. In the empirical model (1), every interaction between Investments $s_{c}$ and a date indicator is an endogenous variable so that the first stage for (1) is a system of equations - one equation for each interaction between Investments $s_{c}$ and the indicator for date $\tau \in$

\footnotetext{
${ }^{16}$ Note that this holds even conditional on the number of children of schooling age, which determines the demand for schools. If the number of students and the space every student requires are held constant, a higher number of schools implies a greater scope for renovations. This is because the volume of a body - in this case, the school building - grows faster than its surface area, and the latter is what matters for a building's energy efficiency.
} 
\{Q1 2006, Q2 2006, .., Q4 2008, Q2 2009, .., Q4 2013\} —of the following form:

$$
\begin{aligned}
& \text { Investments p.c.c } \times \text { Date }_{\tau}=\sum_{t: t \neq \mathrm{Q} 42008} \text { Date }_{t} \times \text { Schools }_{c}^{\prime} \boldsymbol{\Theta}_{t}^{\tau}+\text { CountyF }_{c}^{\tau} \\
& +\sum_{t: t \neq \mathrm{Q} 4} \text { Date }_{t} \times \text { CountyCharacteristics }_{\boldsymbol{c}}^{\prime} \boldsymbol{\Lambda}_{t}^{\tau}+\psi^{\tau} \text { PopGrowt }_{c, t}+\nu_{c, t}^{\tau} \text {, }
\end{aligned}
$$

where Schools $_{\boldsymbol{c}}=($ Academic High Schools p.c.c. Primary and Secondary Schools p.c.c) is a vector containing both categories of schools defined in Section 3.3 and where the index $\tau$ indicates the coefficients of the date- $\tau$ first stage.

A first stage with many endogenous variables and many instruments poses challenges for testing the validity of the instruments in conventional ways. For one, critical values of conventional tests of weak instruments for large numbers of instruments and endogenous variables are unavailable (Stock and Yogo, 2005). Moreover, the first stage (2) is constructed in such a way that Date $_{\tau} \times \boldsymbol{S c h o o l \boldsymbol { s } _ { \boldsymbol { c } }}$, the instruments interacted with the date $\tau$ indicator, are the only instruments with explanatory power for the first stage equation with Investments $_{c} \times$ Date $_{\tau}$ as the dependent variable. Hence, each interaction with an additional date adds two uninformative instruments to each first stage equation, which mechanically reduces the test statistics for joint significance of all the instruments. ${ }^{17}$

Since the first stage is almost exclusively identified from cross-sectional variation, we can infer the strength of the instruments from estimating a simple cross-sectional variant of (2). This is because the system of equations defined by (2) closely resembles a repeated cross-section, one for every date $\times$ investment interaction, since both the instruments and the controls are interacted with date dummies. Indeed, the only variable without a time-varying coefficient on the right-hand side of (2) is population growth. For this reason, this section presents the result of estimating a variant of (2) using only the cross-section of the data in Q4 2008. ${ }^{18}$

Table 1 shows that schools are a strong predictor of total investments in increasingly demanding specifications of the cross-sectional variant of the first stage. Regardless of whether we add the educational composition of the workforce in column (2), the

\footnotetext{
${ }^{17}$ We report the full first stage including test statistics for weak instruments for a version of (1) and (2), in which we group the date interactions of Investments $_{c}$ and $\boldsymbol{S c h o o l s}_{\boldsymbol{c}}$ for the two-year periods before and after the stimulus program as well as for the years during the program in Appendix B.2.

${ }^{18}$ Technically, this means that in (2) all the coefficients with $t \neq \mathrm{Q} 42008$ are set to zero. The choice of Q4 2008 as the date of measurement for the cross-section is completely arbitrary and does not affect the reported results.
} 
Table 1: First Stage

\begin{tabular}{lcccc}
\hline & \multicolumn{3}{c}{ Countercyclical Investments p.c. in $\in 100$ '000 } \\
& $(1)$ & $(2)$ & $(3)$ & $(4)$ \\
\cline { 2 - 5 } Academic High Schools p.c. & $17.47^{* * *}$ & $12.91^{* * *}$ & $11.81^{* * *}$ & $10.09^{* * *}$ \\
& $(2.71)$ & $(2.62)$ & $(2.74)$ & $(2.98)$ \\
Primary \& Second. Schools p.c. & 0.18 & $2.12^{* * *}$ & $2.28^{* * *}$ & $1.53^{* *}$ \\
& $(0.58)$ & $(0.69)$ & $(0.70)$ & $(0.65)$ \\
Empl. Share w College /100 & & $1.25^{* * *}$ & $1.17^{* * *}$ & $0.71^{* *}$ \\
& & $(0.36)$ & $(0.36)$ & $(0.34)$ \\
Empl. Share w Vocational Tr. /100 & -0.14 & -0.08 & -0.10 \\
& & $(0.21)$ & $(0.22)$ & $(0.20)$ \\
Share School-Age Pop /100 & & -0.64 & 0.01 \\
& & & $(0.44)$ & $(0.42)$ \\
Universities p.c. & & & $85.19^{* * *}$ \\
& & & & $(21.92)$ \\
Hospitals p.c. & & & 4.35 \\
& & & & $(2.95)$ \\
\hline State $\times$ UrbanIndex FE & yes & yes & yes \\
Kleibergen-Paap F & 0.15 & 0.12 & 0.11 & 9.77 \\
Shea Partial R & & & & 0.07 \\
Observations & 400 & 400 & 400 & 400 \\
\hline
\end{tabular}

Notes. The dependent variable Countercyclical Investments p.c. in $€ 100$ '000 is the sum of investments normalized by the working-age population (indicated by "p.c." for "per capita") over the years 2009 to 2011. Academic High Schools p.c. is the number of high schools in a county that award the "Abitur," the entry requirement for universities. Primary and Secondary Schools p.c. is the total number of primary schools and secondary schools that offer degrees that allow the pursuit of vocational training. Empl. Share w College and Empl. Share w Vocational Tr. are the share of employees with a college degree and vocational training, respectively. Share School-Age Pop is the number of individuals between 6 and 18 years of age as a fraction of the working-age population. Universities p.c. and Hospitals p.c. are the number of universities and hospitals. State $\times$ UrbanIndex FE are fixed effects for the interaction of indicator variables for the German states and for the values of a four-point urbanization index. Academic High Schools p.c. and Primary and Secondary Schools p.c. are the excluded instruments for the Kleibergen-Paap F statistic and the Shea Partial $R^{2}$. The sample is the cross-section of counties as measured in Q4 2008. Robust standard errors are in parentheses.

${ }^{*} p<0.10,{ }^{* *} p<0.05,{ }^{* * *} p<0.01$. 
short-run demand for schools (the school-age population) in column (3), or other determinants of infrastructure investments (the number of hospitals and universities) in column (4), the Kleibergen-Paap Wald statistic of the instruments remains above or very close to the conventional critical value of ten. We also report the Shea Partial $R^{2}$ of the instruments. The Shea Partial $R^{2}$ varies less with the inclusion of uninformative instruments than the F statistic so that the comparison of the Shea Partial $R^{2}$ from the full system of first stage equations as described by (2) with the one from the cross-section as reported in Table 1 provides a useful assessment of the strength of the instruments in the full, dynamic model.

To interpret the coefficients, note that they represent the average increase in investments (in €100'000) due to one additional school. This is because both schools and investments are normalized by the working-age population. One additional academic high school is hence associated with an increase in investments between $€ 10.1$ and $€ 17.5$ million, while one additional primary or secondary school leads to an increase in investments of $€ 0.2$ to $€ 2.3$ million. ${ }^{19}$

In Table 9 of Appendix B.1, we show that the number of schools predominantly explains investments in schools. ${ }^{20}$ The results in Table 9 also shed light on the relatively large difference between academic high schools and primary and secondary schools in terms of the funding obtained per school. While parts of this difference may be due to academic high schools being significantly larger than primary and secondary schools (see Section 3.3and Appendix A.2), another part of the explanation is that academic high schools received, on average, twice as many projects as primary and secondary schools.

\subsection{Exclusion Restriction}

The second main assumption of the IV strategy is the exclusion restriction, which requires the errors $\varepsilon_{c, t}$ to be independent of the instruments. This implies that, conditional on the covariates, schools may be correlated with employment outcomes only via their effect on investments. Consistent with this assumption, Section 6.1 shows that instrumented investments are indeed unrelated to employment outcomes before

\footnotetext{
${ }^{19}$ Note that the number of hospitals and universities is positively associated with investments as well, as should be expected given the legal requirements of the investment program.

${ }^{20}$ Because project descriptions are unavailable in the data on investments used in the main body of the paper, the analyses in Appendix B.1 use a different, slightly incomplete, data set on investments that includes the project descriptions.
} 
Figure 3: The Autocorrelation of Schools between 1995 and 2008

(a) Primary and Secondary Schools

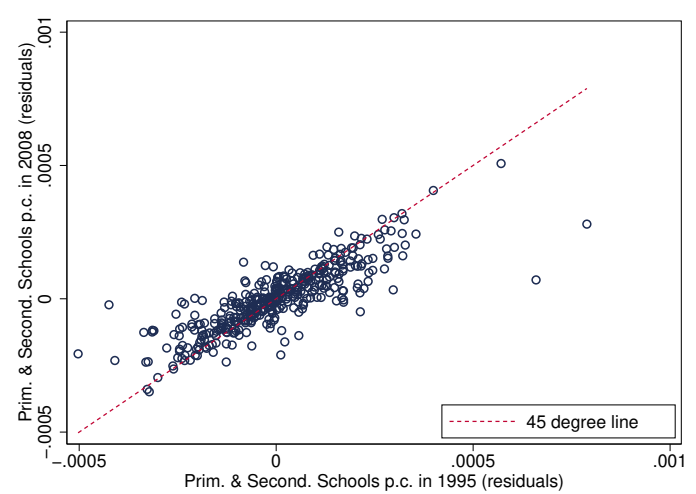

(b) Academic High Schools

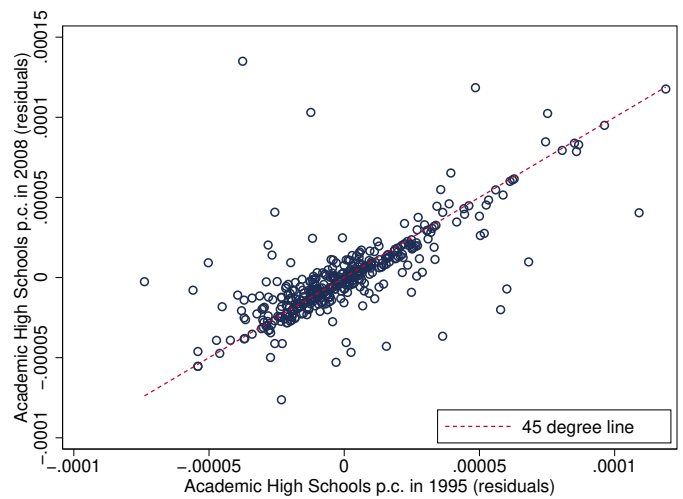

Notes. This figure displays, for each county, the number of schools (net of their state-specific averages and separately for academic high schools and primary and secondary schools) in 2008 against the number of schools in 1995.

the enactment of the stimulus program in Q1 2009.

For the time after the enactment of the program, the exclusion restriction is untestable. However, the number of schools in Germany is very persistent over time and hence unlikely to be correlated with the economic conditions in the short or medium run. Figure 3 illustrates this persistence by plotting the number of schools in 2008 against the number of schools in 1995 (the earliest date at which this data is available). At both years, schools are measured relative to their state averages. For both Academic High Schools and Primary and Secondary Schools, the data is tightly clustered around the 45-degree line. This demonstrates that there are, indeed, at best minor changes in the number of schools over time. ${ }^{21}$

The age distribution of public buildings from the German census of 2011 offers another view of the persistence of schools. Of all non-residential public buildings with one housing unit - the building category applicable to schools that comprise housing for the school's caretaker - 43 percent were constructed before 1948, 84 percent before 1978, and 93 percent before 1995. ${ }^{22}$ The data hence indicates that the existing stock of school buildings was predominantly constructed either prior to 1948, possibly at

\footnotetext{
${ }^{21}$ This is particularly true for the counties in the former West German states. The number of schools in the former East German states is less persistent, possibly due to numerous reforms in the wake of reunification. See Figure 5 in Appendix B.3.

${ }^{22}$ More precise data on the age distribution of school buildings is unavailable. However, anecdotal evidence suggests that the vast majority of schools comprises a housing unit.
} 
Figure 4: Employment Dynamics

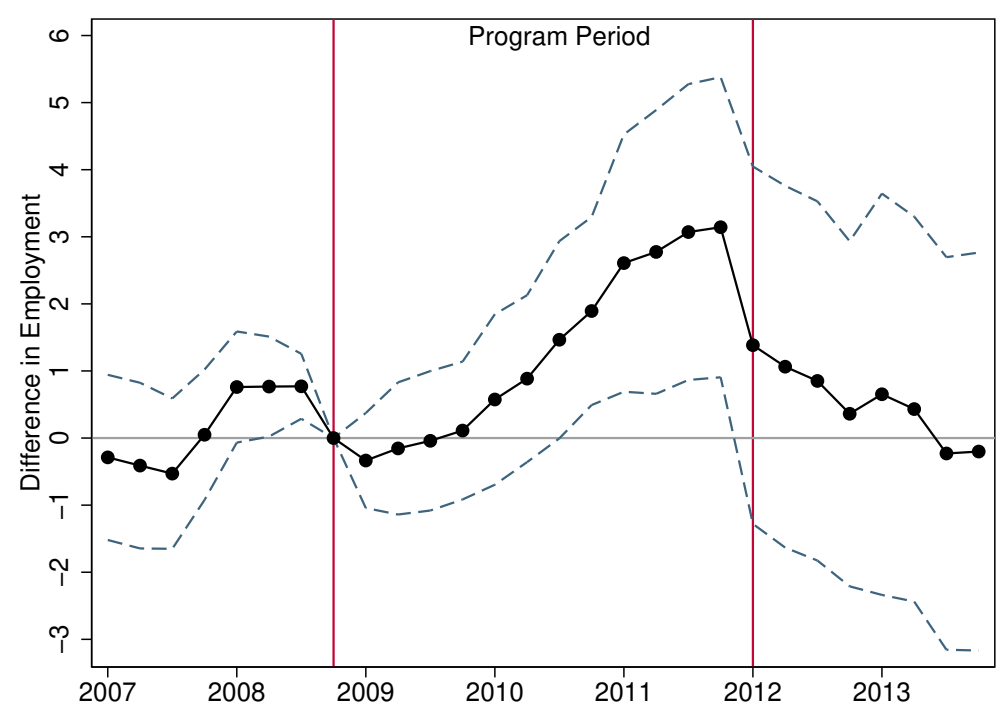

Notes. This figure shows the differences in employment per $€ 100$ '000 invested, $\beta_{t}$, at each quarterly date $t$ between Q1 2007 and Q4 2013 relative to Q4 2008, as well as their 90 percent confidence interval as estimated via IV. The model includes the most comprehensive set of covariates, identical to the one used in column (4) of Table (2). The left vertical line indicates the last date before the investment program was passed into law; the right line indicates the first date after the end of the program.

the time of the introduction of universal public education in the late 19th century, or during the 1960s and 1970s, when the baby boomer generation was of school-age. The current demand for schools is declining due to population aging and hence is mostly met by the existing buildings. The number of schools has thus predominantly been determined by policy decisions made in the 1970s or earlier so that it is likely that schools are independent of employment outcomes during the recession of 2009.

\section{Results}

This section presents the main findings. The empirical analysis shows that the investment program increased employment at low costs, with employment rising three quarters after the program's enactment. The employment gains were accompanied by a drop in unemployment and were concentrated within the construction related sectors as well as the local non-tradable sectors. 


\subsection{Employment Dynamics}

Figure 4 displays the employment dynamics caused by countercyclical investments.

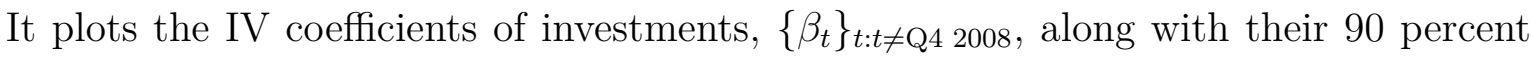
confidence interval, estimated using the model described by equations (1) and (2). Each coefficient $\beta_{t}$ measures the average difference in the employment rate at date $t$ relative to Q4 2008 for additional investments of €100'000 per capita. As both employment and investments are normalized by the working-age population, the coefficients can also be interpreted as the difference in the number of employees between date $t$ and Q4 2008 per €100'000 invested.

The figure shows that, after the passage of the stimulus bill in Q1 2009, the first date to the right of the first vertical line, employment started to increase with a lag of three to four quarters in response to investments. Given that the first parliamentary hearing of the bill took place in January 2009, when it was widely believed that the bill would be passed into law, this implies a plausible planning period of about nine to twelve months. The employment difference reached its peak of about two to three additional employees per $€ 100$ '000 invested in 2011, before it dropped sharply in Q1 2012, exactly at the time when the investment program ended (indicated by the second vertical line). The employment dynamics are hence similar to the aggregate spending pattern described in Section 2, according to which the majority of federal funds was spent in 2010 and 2011. The dynamics also show that the program had a reasonably quick impact on local economies.

Both before and after the program, the employment differences are, in general, statistically indistinguishable from zero. The post-program differences indicate that the infrastructure investment program temporarily increased employment as intended, generating neither positive employment effects beyond the program's duration nor negative employment reversals. The pre-program employment differences may be interpreted as a plausibility check of the exclusion restriction. If the exclusion restriction holds, so that the number of schools affects employment only via its effect on infrastructure investments, the number of schools should be unrelated to the employment outcomes before the passage of the stimulus bill. It is hence reassuring that the estimated coefficients of instrumented investments, which reflect the cross-sectional variation in the number of schools, are indeed clustered around zero before the investment program was enacted.

To quantify the employment gains, we compute the magnitude of the investment 
program's effect as the total difference in job years caused by investments of $€ 100$ '000 during the program's duration. In Figure 4, this statistic is given by the integral of the employment difference between the two vertical lines indicating the last date before and the first date after the program. The employment gains amount to about four job years - or costs per job year of about $€ 25^{\prime} 000$ - with corresponding 90 percent confidence bounds of 0.2 to 7.8 job years.

Table 2 summarizes these employment effects across specifications. For conciseness we reduce the number of coefficients by estimating the average quarterly employment difference relative to Q4 2008 for all dates before the investment program (Q1 2007 to Q3 2008) and after the end of the program (Q1 2011 to Q4 2013). During the program (2009-2011), we estimate the average employment differences for each year, so that the employment dynamics depicted in Figure 4 can also be read from the tables. ${ }^{23}$

Columns (1) to (4) of Table 2 present IV estimates of increasing demanding empirical specifications corresponding to the respective first stages reported in Table 1. Column (1) reports the coefficient estimates for a model that only includes county fixed effects, date fixed effects on the state $\times$ urbanization level, and population growth as covariates. In column (2) we allow for date-specific effects of the employment structure by education, as the educational attainment of the workforce may be related to the demand for schools - the instrument - and the employment outcomes. ${ }^{24}$ Column (3) adjusts for the short-run demand for schools by controlling for the school-age population as a fraction of the labor force. In column (4) we add the number of hospitals and universities, interacted with date fixed effects, to the model, primarily to capture the determinants of investments stemming from funding lines not related to school renovations.

The findings are similar across all the specifications. Regardless of the covariates

$$
\begin{aligned}
& { }^{23} \text { Formally, we substitute the empirical model (1) with the following slight modification: } \\
& \text { Employment p. } c_{c, t}=\beta_{\text {pre }} \text { Investments }_{c} \times \mathbb{1}(\mathrm{t} \in[\mathrm{Q} 1 \text { 2007,Q3 2008]) } \\
& +\sum_{Y=2009}^{2011} \beta_{Y} \text { Investments }_{c} \times \mathbb{1}(\mathrm{t} \in[\mathrm{Q} 1 \mathrm{Y}, \mathrm{Q} 4 \mathrm{Y}])+\beta_{\text {post }} \text { Investment }_{c} \times \mathbb{1}(t \in[\mathrm{Q} 12012, \mathrm{Q} 4 \text { 2013] })
\end{aligned}
$$

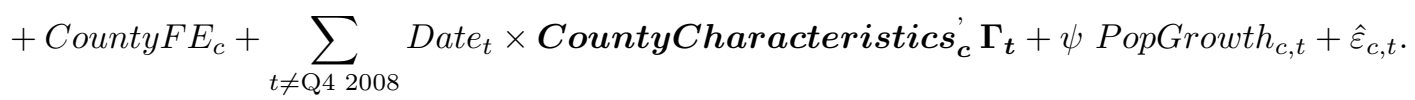

${ }^{24}$ Recall from Section 4 that the controls for the education structure are the shares of employees with a college degree or higher and with vocational training; the omitted category is the share of employees with less than vocational training. All the shares are measured in 2008 and interacted with the full set of quarterly date fixed effects. 
Table 2: The Effects of Countercyclical Investments on Employment

\begin{tabular}{|c|c|c|c|c|c|c|}
\hline & \multicolumn{6}{|c|}{ Employment Rate } \\
\hline & \multicolumn{4}{|c|}{ IV Estimates } & \multicolumn{2}{|c|}{ OLS Estimates } \\
\hline & $(1)$ & $(2)$ & $(3)$ & $(4)$ & $(5)$ & $(6)$ \\
\hline \multicolumn{7}{|l|}{ Investments p.c. } \\
\hline × 2007-Q3 2008 & $\begin{array}{c}0.18 \\
(0.36) \\
\end{array}$ & $\begin{array}{c}0.50 \\
(0.36) \\
\end{array}$ & $\begin{array}{c}0.39 \\
(0.37) \\
\end{array}$ & $\begin{array}{c}0.16 \\
(0.48) \\
\end{array}$ & $\begin{array}{c}-0.11 \\
(0.11) \\
\end{array}$ & $\begin{array}{c}-0.09 \\
(0.13) \\
\end{array}$ \\
\hline$\times 2009$ & $\begin{array}{c}-0.10 \\
(0.37)\end{array}$ & $\begin{array}{c}-0.22 \\
(0.42)\end{array}$ & $\begin{array}{c}0.10 \\
(0.42)\end{array}$ & $\begin{array}{c}-0.10 \\
(0.54)\end{array}$ & $\begin{array}{l}0.35^{* *} \\
(0.16)\end{array}$ & $\begin{array}{c}0.12 \\
(0.15)\end{array}$ \\
\hline$\times 2010$ & $\begin{array}{c}0.87^{* *} \\
(0.43)\end{array}$ & $\begin{array}{c}1.22^{* *} \\
(0.55)\end{array}$ & $\begin{array}{c}1.55^{* *} \\
(0.61)\end{array}$ & $\begin{array}{c}1.21 \\
(0.78)\end{array}$ & $\begin{array}{l}0.44^{*} \\
(0.23)\end{array}$ & $\begin{array}{c}0.12 \\
(0.22)\end{array}$ \\
\hline$\times 2011$ & $\begin{array}{l}2.23^{* * *} \\
(0.67)\end{array}$ & $\begin{array}{l}2.03^{* *} \\
(0.80)\end{array}$ & $\begin{array}{l}2.54^{* * *} \\
(0.89)\end{array}$ & $\begin{array}{l}2.90^{* *} \\
(1.27)\end{array}$ & $\begin{array}{l}0.64^{* *} \\
(0.30)\end{array}$ & $\begin{array}{c}0.36 \\
(0.32)\end{array}$ \\
\hline$\times 2012-2013$ & $\begin{array}{c}2.50^{* *} \\
(1.06)\end{array}$ & $\begin{array}{c}-0.02 \\
(1.17)\end{array}$ & $\begin{array}{c}0.52 \\
(1.26)\end{array}$ & $\begin{array}{c}0.54 \\
(1.67)\end{array}$ & $\begin{array}{c}0.70 \\
(0.45)\end{array}$ & $\begin{array}{c}0.19 \\
(0.44)\end{array}$ \\
\hline County Fixed Effects & yes & yes & yes & yes & yes & yes \\
\hline Population Growth & yes & yes & yes & yes & yes & yes \\
\hline \multicolumn{7}{|l|}{ Date Fixed Effects $\times$} \\
\hline State $\times$ UrbanIndex & yes & yes & yes & yes & yes & yes \\
\hline Emp. Shares by Educ. & no & yes & yes & yes & no & yes \\
\hline School Age Population & no & no & yes & yes & no & yes \\
\hline Universities \& Hospitals & no & no & no & yes & no & yes \\
\hline $\min \left(\right.$ Shea Partial $\left.\mathrm{R}^{2}\right)$ & 0.15 & 0.12 & 0.11 & 0.07 & & 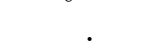 \\
\hline Job Years & 2.99 & 3.03 & 4.19 & 4.00 & 1.43 & 0.60 \\
\hline $90 \%$ CI of Job Years & {$[0.9 ; 5.1]$} & {$[0.4 ; 5.6]$} & {$[1.3 ; 7.0]$} & {$[0.2 ; 7.8]$} & {$[0.4 ; 2.5]$} & {$[-0.4 ; 1.6]$} \\
\hline Costs per Job Year & 33401 & 32964 & 23862 & 25001 & 69980 & 166670 \\
\hline SE Costs per Job Year & 14022 & 17083 & 9880 & 14458 & 30630 & 173316 \\
\hline Observations & 11200 & 11200 & 11200 & 11200 & 11200 & 11200 \\
\hline
\end{tabular}

Notes. The dependent variable is the employment rate on each quarterly date between Q1 2007 and Q4 2013. Investments p.c. $\times 2007-Q 32008$ is the interaction of investments in €100'000 with an indicator that equals one for the observations between 2007 and Q3 2008. All the other interactions are defined accordingly; the baseline is Q4 2008. The horizontal lines between the estimates indicate the beginning and the end of the stimulus program. Population Growth is the ratio of the current workingage population and the working-age population in 2008. The following variables, measured in 2008, are interacted with the full set of date fixed effects: State $\times$ UrbanIndex (interactions of indicators for the states and the values of the urbanization index), Emp. Shares by Educ. (shares of employees with a college degree and with vocational training), School-Age Population, and Universities and Hospitals. Min(Shea Partial $R^{2}$ ) reports the minimum of the Shea $R^{2}$ of the excluded instruments - the date interactions of Academic High Schools p.c. and Primary and Secondary Schools p.c.- -among all the first stages (one for each interaction of Investments p.c.). The number of Job Years is the sum of the coefficients of Investments p.c. between 2009 and 2011. Costs per Job Year equal 100'000/Job Years. The confidence intervals of Job Years and the standard errors of Costs per Job Year are calculated via the Delta method. Standard errors clustered at the county level are in parentheses.

$* p<0.10,{ }^{* *} p<0.05,{ }^{* * *} p<0.01$. 
included, the investment-induced employment differences are statistically indistinguishable from zero before the investment program. After the program, the average employment difference is only positive in the most parsimonious specification, and statistically zero in the remaining ones. When the program was active, in contrast, we find positive and economically relevant employment differences of 0.9 to 1.5 in 2010 and 2 to 2.9 in 2011 per $€ 100$ '000 invested. With the exception of the coefficient for 2010 in column (4), which has a p-value of 0.12 , these coefficients are statistically significant at least at the five percent level. The estimates translate into three to four job years per €100'000 spent, or into costs per job year between €25'000 and €33'000. Given the standard errors of the estimated costs per job year calculated via the Delta method, the bounds of the union of all 90 percent confidence sets of the costs per job year across specifications are $€ 1$ ' 144 and $€ 61 ' 150 .^{25}$

In addition to the IV estimates, Columns (5) and (6) of Table 2 present the OLS estimates of the most parsimonious and the most demanding specifications, respectively. The estimated employment differences during the program period in column (5) are at most half as large as the corresponding IV estimates. These estimates imply that 1.4 job years were created per $€ 100$ '000 spent, so the costs per job year are about $€ 70$ '000. Adding covariates, however, leads to a sharp drop in the coefficients, so the employment gains of the program become statistically indistinguishable from zero and economically irrelevant.

The magnitude of the employment effect can be interpreted by comparing the baseline estimate of the costs per job year in column (4) of Table 2-€25’000 - with the wages in construction, the main target industry of the investment program. Since there is no information on the marginal worker employed through the investment program, we use different yearly wages for this comparison: the minimum wage in construction of about $€ 23$ '000, the union wages of construction workers ranging from $€ 30$ '000 to $€ 38$ '000, or the average labor costs in the entire construction sector (including administrative and management jobs) of about $€ 45^{\prime} 000 .^{26}$ These wages imply substantial

\footnotetext{
${ }^{25}$ Columns (1) to (4) of Table 2 also report the minima of the Shea Partial $R^{2}$ across all the first stage equations of the relevant model to facilitate the comparison of the instruments' strength with the corresponding cross-sectional first stage equation in Table 1. Because the first stage is identified exclusively from cross-sectional variation, it comes as no surprise that the minima of the Shea Partial $R^{2}$ are equal to the ones from the cross-sections. For additional details on the first stage see Appendix B.2, which reports the complete first stage estimates corresponding to column (4) of Table 2.

${ }^{26}$ The minimum wages are published by the German secretary of commerce (http://www.bmwi.de/DE/Themen/Wirtschaft/branchenfokus,did=313190.html), the union wages are published by the Boeckler foundation (http://www.boeckler.de/wsi-tarifarchiv_4428.htm), and
} 
"wage multipliers," the ratio between the wage and the costs per job year, between 0.9 and 1.8 .

The costs per job year from the German countercyclical investment program are of a similar magnitude to the findings of a substantial share of the recent literature that estimates the effects of fiscal policy on local economies. For contractions in infrastructure investments, Acconcia et al. (2014) find a local income multiplier of 1.5 to 2.0. The $€ 25$ '000 costs per job year correspond to $\$ 34$ '200 when using the average eurodollar exchange rate during the program. Several studies on the effects of aggregate local fiscal spending in the U.S. find costs per job year of a similar size. For Medicaid transfers in the context of the ARRA, Chodorow-Reich et al. (2012) find costs per job year of $\$ 26 ’ 000$. For highway construction during normal times, Leduc and Wilson (2013) estimate local income multipliers between 3 and 8. Using windfalls in general public spending, Shoag (2010) and Suárez Serrato and Wingender (2016) find costs per job year of $\$ 35^{\prime} 000$ and $\$ 30^{\prime} 000$, respectively. Both these studies also find local income multipliers of 2.1 and 1.7 to 2.0. Assuming a labor share of income of twothirds, this implies a wage multiplier of roughly 1.3, which is well in the range of the back-of-the-envelope estimates of the wage multiplier from the previous paragraph. ${ }^{27}$

\subsection{Investments Reduce Unemployment}

The results so far show that the countercyclical investments increased employment quickly and cost-effectively. These employment gains could arise from different sources: a reduction in unemployment, a reduction in the number of inactive individuals who are neither employed nor unemployed, or flows out of self-employment into formal employment, as the German employment data lacks information on self-employment. Of these possibilities, flows out of unemployment are likely to generate rather sizable economic gains, as they mobilize slack economic resources and reduce government transfers. Moreover, preventing an increase in unemployment was the major policy objective of the investment program. In this section, we thus ask whether investments led to a reduction - or prevented an increase - in unemployment.

the labor costs are published by the German statistical office (series 62411). If the data distinguishes between Western and Eastern Germany, we report the wages from West Germany. Hourly wages are translated into yearly wages assuming a 40-hour work week. The data was accessed on November 25 , 2016.

${ }^{27}$ These results suggest that fiscal policy is highly effective in stimulating local economies. However, there are also a few studies (e.g., Conley and Dupor, 2013; Garin, 2016) that reach the opposite conclusion. 
Table 3: The Effects of Countercyclical Investments on Unemployment

\begin{tabular}{|c|c|c|c|c|c|c|}
\hline \multirow[b]{4}{*}{ Investments p.c. } & \multicolumn{6}{|c|}{ Unemployment Rate } \\
\hline & \multicolumn{4}{|c|}{ IV Estimates } & \multicolumn{2}{|c|}{ OLS Estimates } \\
\hline & \multirow[t]{2}{*}{$(1)$} & \multirow[t]{2}{*}{$(2)$} & \multirow[t]{2}{*}{ (3) } & \multirow[t]{2}{*}{$(4)$} & \multirow[t]{2}{*}{$(5)$} & \multirow[t]{2}{*}{$(6)$} \\
\hline & & & & & & \\
\hline × 2007-Q3 2008 & $\begin{array}{c}0.44 \\
(0.52)\end{array}$ & $\begin{array}{c}0.35 \\
(0.54)\end{array}$ & $\begin{array}{c}0.02 \\
(0.52)\end{array}$ & $\begin{array}{c}0.50 \\
(0.76)\end{array}$ & $\begin{array}{c}0.22 \\
(0.22)\end{array}$ & $\begin{array}{c}0.29 \\
(0.27)\end{array}$ \\
\hline$\times 2009$ & $\begin{array}{c}0.40 \\
(0.42)\end{array}$ & $\begin{array}{c}0.14 \\
(0.44)\end{array}$ & $\begin{array}{c}0.14 \\
(0.44)\end{array}$ & $\begin{array}{c}-0.01 \\
(0.62)\end{array}$ & $\begin{array}{r}-0.07 \\
(0.17)\end{array}$ & $\begin{array}{c}0.04 \\
(0.19)\end{array}$ \\
\hline$\times 2010$ & $\begin{array}{c}0.06 \\
(0.52)\end{array}$ & $\begin{array}{c}-0.69 \\
(0.61)\end{array}$ & $\begin{array}{r}-0.58 \\
(0.63)\end{array}$ & $\begin{array}{c}-0.86 \\
(0.84)\end{array}$ & $\begin{array}{c}-0.06 \\
(0.22)\end{array}$ & $\begin{array}{c}-0.02 \\
(0.25)\end{array}$ \\
\hline$\times 2011$ & $\begin{array}{c}-0.76 \\
(0.61) \\
\end{array}$ & $\begin{array}{c}-1.56^{* *} \\
(0.69)\end{array}$ & $\begin{array}{c}-1.44^{* *} \\
(0.71)\end{array}$ & $\begin{array}{c}-2.08^{* *} \\
(1.01) \\
\end{array}$ & $\begin{array}{r}-0.07 \\
(0.25) \\
\end{array}$ & $\begin{array}{r}-0.07 \\
(0.30) \\
\end{array}$ \\
\hline$\times 2012-2013$ & $\begin{array}{c}-0.60 \\
(0.64) \\
\end{array}$ & $\begin{array}{c}-1.69^{* *} \\
(0.78) \\
\end{array}$ & $\begin{array}{r}-1.47^{*} \\
(0.80) \\
\end{array}$ & $\begin{array}{c}-2.45^{* *} \\
(1.14)\end{array}$ & $\begin{array}{r}-0.02 \\
(0.26) \\
\end{array}$ & $\begin{array}{r}-0.12 \\
(0.30) \\
\end{array}$ \\
\hline County Fixed Effects & yes & yes & yes & yes & yes & yes \\
\hline Population Growth & yes & yes & yes & yes & yes & yes \\
\hline \multicolumn{7}{|l|}{ Date Fixed Effects $\times$} \\
\hline State $\times$ UrbanIndex & yes & yes & yes & yes & yes & yes \\
\hline Emp. Shares by Educ. & no & yes & yes & yes & no & yes \\
\hline School Age Population & no & no & yes & yes & no & yes \\
\hline Universities \& Hospitals & no & no & no & yes & no & yes \\
\hline $\min \left(\right.$ Shea Partial R $\left.{ }^{2}\right)$ & 0.15 & 0.12 & 0.11 & 0.07 & . & . \\
\hline Job Years & 0.30 & 2.11 & 1.88 & 2.95 & 0.19 & 0.05 \\
\hline $90 \%$ CI of Job Years & {$[-2.0 ; 2.6]$} & {$[-0.5 ; 4.7]$} & {$[-0.8 ; 4.6]$} & {$[-0.8 ; 6.7]$} & {$[-0.8 ; 1.2]$} & {$[-1.1 ; 1.2]$} \\
\hline Costs per Job Year & 330492 & 47314 & 53102 & 33861 & 526480 & 2196241 \\
\hline SE Costs per Job Year & 1537140 & 35844 & 45834 & 25889 & 1661597 & 34027952 \\
\hline Observations & 11200 & 11200 & 11200 & 11200 & 11200 & 11200 \\
\hline
\end{tabular}

Notes. The dependent variable is the unemployment rate on each quarterly date between Q1 2007 and Q4 2013. Investments p.c. $\times 2007-Q 32008$ is the interaction of investments in €100'000 with an indicator that equals one for the observations between 2007 and Q3 2008. All the other interactions are defined accordingly; the baseline is Q4 2008. The horizontal lines between the estimates indicate the beginning and the end of the stimulus program. Population Growth is the ratio of the current workingage population and the working-age population in 2008. The following variables, measured in 2008, are interacted with the full set of date fixed effects: State $\times$ UrbanIndex (interactions of indicators for the states and the values of the urbanization index), Emp. Shares by Educ. (shares of employees with a college degree and with vocational training), School-Age Population, and Universities and Hospitals. Min(Shea Partial $R^{2}$ ) reports the minimum of the Shea $R^{2}$ of the excluded instruments - the date interactions of Academic High Schools p.c. and Primary and Secondary Schools p.c.- -among all the first stages (one for each interaction of Investments p.c.). The number of Job Years is the sum of the coefficients of Investments p.c. between 2009 and 2011. Costs per Job Year equal 100'000/Job Years. The confidence intervals of Job Years and the standard errors of Costs per Job Year are calculated via the Delta Method. Standard errors clustered at the county level are in parentheses.

$* p<0.10,{ }^{* *} p<0.05,{ }^{* * *} p<0.01$. 
Table 3 reports the estimates of the same empirical specifications as Table 2, but this time with the unemployment rate as the dependent variable. The most parsimonious IV specification in column (1) does not detect statistically significant effects, even though larger investments are associated with decreasing unemployment. Adding covariates in columns (2) to (4), however, leads to estimated employment differences similar to the corresponding employment effects. Mirroring the employment dynamics, unemployment starts to decrease in 2010, and the effects peak in 2011. While the program was active, investments of $€ 100$ '000 reduced unemployment by 1.9 to 3.0 person years, implying costs per "job" years between $€ 34$ '000 and €53'000. The reductions in unemployment thus amount to one-half to two-thirds of the respective employment gains. A notable difference from the employment effects, however, is that the unemployment effect persists into the post-program period. This could be in line with the fading employment effect if parts of the individuals formally employed via the program became self-employed when the investment projects were completed. Finally, as regards employment, the OLS estimates of the unemployment effects are statistically insignificant and considerably smaller than the corresponding IV estimates.

\subsection{Investments and Employment Gains across Industries}

A feature of investment programs is that they target specific industries so that there is a clear hypothesis regarding which industries should experience employment gains. The German investment program focused on stimulating local economies mainly by financing the energy-saving remodeling of buildings. The program was thus, in the first place, a building construction program. ${ }^{28}$ As a consequence, we expect to find employment gains predominantly in construction related industries as well as in local non-tradable industries.

To test this hypothesis, we analyze the effect of infrastructure investments on employment in the two "treated" industries, construction and local non-tradables, as well as on employment in the remaining "untreated" sectors. The partition of the total employment into these three subgroups is based on counties' employment statistics at the three-digit industry level as classified by the German Classification of Economic Activities (Klassifikation der Wirtschaftszweige 2008). The data appendix (Appendix 3) provides the details regarding which industries are assigned to which of the three

\footnotetext{
${ }^{28}$ Funds were used for other purposes as well, though. For example, the project lists underlying the investment data used in Appendix B.1 indicate that some schools used the investment funds to upgrade their IT equipment.
} 
subgroups.

Table 4 reports the results of estimating the main empirical model (1) both via IV and via OLS with the full set of controls and with the three groups of employment by industry as dependent variables. These results correspond to the estimates of the aggregate employment gains reported in Columns (4) - IV — and (6) - OLS - of Table 2, respectively. Note, however, that the estimates are not fully comparable across Tables 2 and 4, as the employment data at the industry level is truncated at zero for countyindustry cells with few observations and only available from 2008 onward due to the major revision of the industry classification in that year.

The IV estimates in Columns (1), (3), and (5) show that the main employment effect originates almost exclusively from the targeted industries. Of the total employment gains of 3.49 job years per investment of $€ 100 ' 000$ estimated with the industry specific data, 1.44 job years are gained in construction-related industries, and 1.54 job years are gained in non-tradable industries. The untreated sectors amount to only 0.54 job years. The IV results thus show that the investment program created employment in the targeted industries. The converse holds for the OLS estimates, for which only 0.04 job years of the total employment gains of 0.82 job years can be attributed to the treated industries combined, while 94 percent of the job gains are attributed to industries that should have been unaffected by the program. One interpretation that is consistent with the latter finding is that state governments indeed channeled funds into counties in which (manufacturing) industries were expected to be hit the hardest by the recession so that the association between investments and employment gains in these industries picks up the recovery of manufacturing after the crisis.

\subsection{Geographical Spillovers and Robustness}

A plausible concern regarding our findings so far is that the employment effects may be over- or underestimated due to geographical spillovers. For example, the estimated effects would be too large if investments in one county increased the local wages and thus reduced the employment in other counties within the same region. In contrast, the estimated employment effects would be too small if there were sizable demand spillovers across counties so that an increase in the labor demand within one county boosts employment in adjacent counties as well.

To test whether there are geographical spillovers of an economically significant size, we follow the approach of Acconcia et al. (2014) and add investments in neighboring 
Table 4: The Employment Effects of Investments by Industry

\begin{tabular}{|c|c|c|c|c|c|c|}
\hline & \multicolumn{2}{|c|}{ Construction } & \multicolumn{2}{|c|}{$\begin{array}{c}\text { Employment p.c. in } \\
\text { Non-tradables }\end{array}$} & \multicolumn{2}{|c|}{ Other Industries } \\
\hline & $\begin{array}{l}\text { IV } \\
(1)\end{array}$ & $\begin{array}{l}\text { OLS } \\
(2)\end{array}$ & $\begin{array}{l}\text { IV } \\
(3)\end{array}$ & $\begin{array}{l}\text { OLS } \\
(4)\end{array}$ & $\begin{array}{l}\text { IV } \\
(5)\end{array}$ & $\begin{array}{c}\text { OLS } \\
(6)\end{array}$ \\
\hline \multicolumn{7}{|l|}{ Investments p.c. } \\
\hline × Q1 2008-Q3 2008 & $\begin{array}{c}0.02 \\
(0.11)\end{array}$ & $\begin{array}{c}-0.01 \\
(0.03)\end{array}$ & $\begin{array}{c}-0.02 \\
(0.11)\end{array}$ & $\begin{array}{c}-0.02 \\
(0.04)\end{array}$ & $\begin{array}{c}0.54 \\
(0.36)\end{array}$ & $\begin{array}{c}0.05 \\
(0.11)\end{array}$ \\
\hline$\times 2009$ & $\begin{array}{c}0.27^{*} \\
(0.15)\end{array}$ & $\begin{array}{c}0.05 \\
(0.04)\end{array}$ & $\begin{array}{l}0.62^{* *} \\
(0.25)\end{array}$ & $\begin{array}{c}-0.01 \\
(0.05)\end{array}$ & $\begin{array}{c}-0.70 \\
(0.57)\end{array}$ & $\begin{array}{c}0.15 \\
(0.14)\end{array}$ \\
\hline$\times 2010$ & $\begin{array}{c}0.30 \\
(0.22)\end{array}$ & $\begin{array}{c}0.04 \\
(0.06)\end{array}$ & $\begin{array}{c}0.40 \\
(0.36)\end{array}$ & $\begin{array}{c}-0.05 \\
(0.08)\end{array}$ & $\begin{array}{c}0.24 \\
(0.67)\end{array}$ & $\begin{array}{c}0.21 \\
(0.22)\end{array}$ \\
\hline$\times 2011$ & $\begin{array}{r}0.86^{*} \\
(0.50)\end{array}$ & $\begin{array}{c}0.07 \\
(0.19)\end{array}$ & $\begin{array}{c}0.49 \\
(0.50)\end{array}$ & $\begin{array}{c}-0.05 \\
(0.11)\end{array}$ & $\begin{array}{c}1.00 \\
(1.12)\end{array}$ & $\begin{array}{c}0.41 \\
(0.37)\end{array}$ \\
\hline$\times 2012-2013$ & $\begin{array}{c}0.79 \\
(0.50)\end{array}$ & $\begin{array}{c}0.07 \\
(0.14)\end{array}$ & $\begin{array}{c}0.12 \\
(0.65)\end{array}$ & $\begin{array}{c}-0.19 \\
(0.17)\end{array}$ & $\begin{array}{c}-0.64 \\
(1.51)\end{array}$ & $\begin{array}{c}0.43 \\
(0.44)\end{array}$ \\
\hline County Fixed Effects & yes & yes & yes & yes & yes & yes \\
\hline Population Growth & yes & yes & yes & yes & yes & yes \\
\hline \multicolumn{7}{|l|}{ Date Fixed Effects $\times$} \\
\hline State $\times$ UrbanIndex & yes & yes & yes & yes & yes & yes \\
\hline Emp. Shares by Educ. & yes & yes & yes & yes & yes & yes \\
\hline School Age Population & yes & yes & yes & yes & yes & yes \\
\hline Universities \& Hospitals & yes & yes & yes & yes & yes & yes \\
\hline $\min \left(\right.$ Shea Partial $\left.\mathrm{R}^{2}\right)$ & 0.07 & . & 0.07 & . & 0.07 & \\
\hline Job Years & 1.44 & 0.16 & 1.51 & -0.12 & 0.54 & 0.77 \\
\hline $90 \%$ CI of Job Years & {$[0.2 ; 2.7]$} & {$[-0.3 ; 0.6]$} & {$[-0.2 ; 3.2]$} & {$[-0.5 ; 0.3]$} & {$[-2.8 ; 3.8]$} & {$[-0.3 ; 1.9]$} \\
\hline Observations & 9600 & 9600 & 9600 & 9600 & 9600 & 9600 \\
\hline
\end{tabular}

Notes. The dependent variable is employment in construction related industries (columns (1) and $(2)$ ), non-tradable industries (columns (3) and (4)), and all remaining industries (columns (5) and (6)) on each quarterly date between Q1 2008 and Q4 2013, normalized by the working-age population. Investments p.c. $\times$ Q1 2008-Q3 2008 is the interaction of investments in $€ 100$ '000 with an indicator that equals one for the observations between Q1 and Q3 2008. All the other interactions are defined accordingly; the baseline is Q4 2008. The horizontal lines between the estimates indicate the beginning and the end of the stimulus program. All the remaining variables and statistics are described in Tables 2 and 3. Standard errors clustered at the county level are in parentheses.

${ }^{*} p<0.10,{ }^{* *} p<0.05,{ }^{* * *} p<0.01$. 
counties as an additional variable to the main empirical specification. For each county we consider three possibile definitions of neighboring counties: all other counties within the same labor market region (Raumordnungsregion), the five closest counties based on the distance between the two counties' most populous municipalities, and the ten closest counties. For each set of a county's neighbors, we calculate investment spillovers as the total investments within the set of neighboring counties, normalized by the county's working-age population. These investment spillovers are instrumented by the aggregate number of schools within the set of neighboring counties (normalized by the county's working-age population).

Table 5 reports the IV estimates of the investment-induced employment gains that include potential investment spillovers. The effect of investments in neighboring counties on a county's employment is negative in general and more than one order of magnitude smaller than the direct employment effects. This suggests that the investment program did not lead to major geographic shifts in economic activities across counties so that geographical spillovers should be of little concern.

In Table 6 we evaluate the robustness of the empirical results with respect to a number of alternative specifications. For brevity, each row of Table 6 documents the results of a different specification and reports the average employment difference in 2011 (the peak of the employment gains in the main specification) and its standard error clustered at the county level, the minimum of the Shea Partial $R^{2}$ of all the first stages, the number of job years and its standard error, the costs per job year, and the number of observations. For comparison, row (0) reports these statistics for the most demanding of the main specifications (column (4) of Table 2), which serves as the baseline for all robustness checks. Before going into details, note that all the robustness checks, except those using only the East German sample in rows (5) and (10), yield estimates for the costs per job year that are within one standard deviation of the baseline estimate.

The first set of robustness checks alters the specification of the empirical model or the estimation strategy. Row (1) estimates the baseline specification using the low information maximum likelihood (LIML) estimator, which is less susceptible to weak IV bias, but less precise. Weak IV bias may be an issue for the most demanding specification, as the Kleibergen-Paap F statistic of the first stage is close to the common critical value of 10 (Table 1). It is thus reassuring that the LIML estimates are very close to their 2SLS counterparts. In row (2) we follow parts of the literature (e.g., 
Table 5: The Employment Effects of Investments with Geographical Spillovers

\begin{tabular}{|c|c|c|c|c|}
\hline \multirow[b]{2}{*}{ Set of Neighboring Counties: } & \multicolumn{4}{|c|}{ Employment Rate } \\
\hline & $\begin{array}{l}\text { Baseline } \\
\quad(1)\end{array}$ & $\begin{array}{l}\text { Labor Market } \\
(2)\end{array}$ & $\begin{array}{l}5 \text { Closest } \\
(3)\end{array}$ & $\begin{array}{l}10 \text { Closest } \\
\text { (4) }\end{array}$ \\
\hline $\begin{array}{l}\text { Investments p.c. } \\
\quad \times 2007-\mathrm{Q} 32008\end{array}$ & $\begin{array}{c}0.16 \\
(0.48)\end{array}$ & $\begin{array}{c}0.09 \\
(0.45)\end{array}$ & $\begin{array}{c}0.12 \\
(0.52)\end{array}$ & $\begin{array}{c}0.20 \\
(0.47)\end{array}$ \\
\hline$\times 2009$ & $\begin{array}{c}-0.10 \\
(0.54)\end{array}$ & $\begin{array}{c}0.40 \\
(0.68)\end{array}$ & $\begin{array}{c}0.26 \\
(0.63)\end{array}$ & $\begin{array}{c}0.12 \\
(0.67)\end{array}$ \\
\hline$\times 2010$ & $\begin{array}{c}1.21 \\
(0.78)\end{array}$ & $\begin{array}{c}2.12^{* *} \\
(0.93)\end{array}$ & $\begin{array}{c}1.98^{* *} \\
(0.95)\end{array}$ & $\begin{array}{c}1.79^{*} \\
(0.92)\end{array}$ \\
\hline$\times 2011$ & $\begin{array}{l}2.90^{* *} \\
(1.27)\end{array}$ & $\begin{array}{l}4.25^{* * *} \\
(1.32)\end{array}$ & $\begin{array}{l}3.66^{* *} \\
(1.45)\end{array}$ & $\begin{array}{l}3.56^{* *} \\
(1.39)\end{array}$ \\
\hline$\times 2012-2013$ & $\begin{array}{c}0.54 \\
(1.67)\end{array}$ & $\begin{array}{c}2.29 \\
(1.70)\end{array}$ & $\begin{array}{c}1.24 \\
(1.80)\end{array}$ & $\begin{array}{c}1.54 \\
(1.70)\end{array}$ \\
\hline $\begin{array}{l}\text { Investments in Neighboring } \mathrm{C} \\
\quad \times 2007-\mathrm{Q} 32008\end{array}$ & nties p.c. & $\begin{array}{c}0.00 \\
(0.01)\end{array}$ & $\begin{array}{c}0.01 \\
(0.02)\end{array}$ & $\begin{array}{c}0.01 \\
(0.01)\end{array}$ \\
\hline$\times 2009$ & & $\begin{array}{r}-0.03 \\
(0.02)\end{array}$ & $\begin{array}{c}-0.05^{* *} \\
(0.02)\end{array}$ & $\begin{array}{c}-0.03^{* * *} \\
(0.01)\end{array}$ \\
\hline$\times 2010$ & & $\begin{array}{r}-0.04 \\
(0.03)\end{array}$ & $\begin{array}{c}-0.07^{* *} \\
(0.04)\end{array}$ & $\begin{array}{c}-0.03^{* *} \\
(0.02)\end{array}$ \\
\hline$\times 2011$ & & $\begin{array}{r}-0.01 \\
(0.05)\end{array}$ & $\begin{array}{c}-0.04 \\
(0.06)\end{array}$ & $\begin{array}{c}-0.01 \\
(0.03)\end{array}$ \\
\hline × 2012-2013 & & $\begin{array}{c}-0.01 \\
(0.06)\end{array}$ & $\begin{array}{r}-0.03 \\
(0.08)\end{array}$ & $\begin{array}{r}-0.02 \\
(0.03)\end{array}$ \\
\hline County Fixed Effects & yes & yes & yes & yes \\
\hline Population Growth & yes & yes & yes & yes \\
\hline Date Fixed Effects $\times$ & & & & \\
\hline State $\times$ UrbanIndex & yes & yes & yes & yes \\
\hline Emp. Shares by Educ. & yes & yes & yes & yes \\
\hline School Age Population & yes & yes & yes & yes \\
\hline Universities \& Hospitals & yes & yes & yes & yes \\
\hline $\min \left(\right.$ Shea Partial $\left.\mathrm{R}^{2}\right)$ & 0.07 & 0.09 & 0.06 & 0.07 \\
\hline Job Years & 4.00 & 6.77 & 5.91 & 5.47 \\
\hline $90 \%$ CI of Job Years & {$[0.2 ; 7.8]$} & {$[2.3 ; 11.2]$} & {$[1.4 ; 10.4]$} & {$[1.1 ; 9.8]$} \\
\hline Observations & 11200 & 11200 & 11200 & 11200 \\
\hline
\end{tabular}

Notes. Investments in Neighboring Counties p.c. $\times 2007-Q 32008$ is the interaction of aggregate investments (in €100'000 and normalized by the working-age population) across all other counties in the same labor market region (column (2)), the 5 closest counties (column (3)), or the 10 closest counties (column (4)) interacted with an indicator for the dates 2007-Q3 2008. All the other interactions are defined accordingly. The remaining variables and statistics are described in Table 2. Standard errors are clustered at the level of the 94 labor market regions. ${ }^{*} p<0.10,{ }^{* *} p<0.05,{ }^{* * *} p<0.01$. 
Table 6: Robustness

\begin{tabular}{|c|c|c|c|c|c|c|c|}
\hline & $\beta(2011)$ & $\mathrm{SE}$ & Shea $R^{2}$ & Job Years & SE(Job Yrs) & Costs p. JY & $\mathrm{N}$ \\
\hline (0) Baseline & $2.90^{* *}$ & 1.27 & 0.07 & 4.00 & 2.31 & 25001 & 11200 \\
\hline $\begin{array}{l}\text { Model Variants } \\
\text { (1) LIML } \\
\text { (2) Weighted by labor force pop } \\
\text { (3) Cluster: labor market region } \\
\text { (4) West Germany only } \\
\text { (5) East Germany only } \\
\text { (6) Employment } \geq 25 \text { years of age }\end{array}$ & $\begin{array}{l}3.14^{* *} \\
2.25^{*} \\
2.90^{* *} \\
3.14^{* *} \\
0.71 \\
2.00^{*}\end{array}$ & $\begin{array}{l}1.43 \\
1.17 \\
1.32 \\
1.39 \\
2.78 \\
1.08\end{array}$ & $\begin{array}{l}0.07 \\
0.07 \\
0.07 \\
0.08 \\
0.07 \\
0.07\end{array}$ & $\begin{array}{l}4.33 \\
3.09 \\
4.00 \\
4.30 \\
1.31 \\
2.89\end{array}$ & $\begin{array}{l}2.56 \\
2.26 \\
2.46 \\
2.47 \\
5.68 \\
2.11\end{array}$ & $\begin{array}{l}23107 \\
32368 \\
25001 \\
23270 \\
76436 \\
34570\end{array}$ & $\begin{array}{r}11200 \\
11200 \\
11200 \\
9072 \\
2128 \\
11200\end{array}$ \\
\hline $\begin{array}{l}\text { Instruments } \\
\text { (7) All school types separately } \\
\text { (8) All school types aggregated } \\
\text { (9) Instruments in } 1995 \text { (West Germany) } \\
\text { (10) Instruments in } 1995 \text { (East Germany) } \\
\text { (11) Schools (2008) } \leq \text { Schools (1995) }\end{array}$ & $\begin{array}{l}3.25^{* * *} \\
2.11 \\
2.94^{* *} \\
-2.27 \\
2.96^{* *}\end{array}$ & $\begin{array}{l}1.08 \\
1.34 \\
1.24 \\
2.06 \\
1.40\end{array}$ & $\begin{array}{l}0.10 \\
0.04 \\
0.09 \\
0.06 \\
0.07\end{array}$ & $\begin{array}{r}4.34 \\
3.62 \\
3.08 \\
-2.07 \\
4.43\end{array}$ & $\begin{array}{l}1.94 \\
2.69 \\
2.22 \\
4.45 \\
2.70\end{array}$ & $\begin{array}{r}23059 \\
27611 \\
32505 \\
-48421 \\
22594\end{array}$ & $\begin{array}{r}11200 \\
11200 \\
9072 \\
2128 \\
9688\end{array}$ \\
\hline $\begin{array}{l}\text { Controls } \\
\text { (12) With short-time work } \\
\text { (13) With Bartik shocks (baseline: Q1 09) } \\
\text { (14) With industry structure } \\
\text { (15) Additional age structure controls } \\
(16) \text { Additional age structure by gender } \\
(17) \text { Date } \times \text { state FEs, area p.c. } \\
(18) \text { Date } \times \text { state FEs, area p.c., area }{ }^{2}\end{array}$ & $\begin{array}{l}2.84^{* *} \\
2.74^{* * *} \\
2.78^{* *} \\
4.29^{* *} \\
3.28^{* *} \\
4.04^{* * *} \\
4.01^{* * *}\end{array}$ & $\begin{array}{l}1.27 \\
0.91 \\
1.22 \\
1.67 \\
1.59 \\
1.51 \\
1.50\end{array}$ & $\begin{array}{l}0.07 \\
0.07 \\
0.07 \\
0.06 \\
0.05 \\
0.06 \\
0.06\end{array}$ & $\begin{array}{l}4.23 \\
4.35 \\
4.31 \\
6.67 \\
5.67 \\
6.01 \\
5.94\end{array}$ & $\begin{array}{l}2.33 \\
1.69 \\
2.23 \\
3.04 \\
2.91 \\
2.71 \\
2.70\end{array}$ & $\begin{array}{l}23664 \\
22969 \\
23219 \\
15003 \\
17652 \\
16629 \\
16835\end{array}$ & $\begin{array}{r}11200 \\
8000 \\
11200 \\
11200 \\
11200 \\
11200 \\
11200\end{array}$ \\
\hline
\end{tabular}

Notes. This table presents the results of various modifications of the baseline empirical specification given by column (4) of Table 2. Each row represents the results of a different specification; see the text for details. Column $\beta(2011)$ reports the coefficient estimate of Investments p.c. $\times 2011$; column $S E$ reports its standard errors, clustered at the county level (except for row (3), where standard errors are clustered at the level of the labor market region). Shea $R^{2}$ reports the minimum of the Shea Partial $R^{2}$ of the excluded instruments- the date interactions of Academic High Schools p.c. and Primary and Secondary Schools p.c.- - among all the first stages (one for each interaction of Investments p.c.). The number of Job Years is the sum of the coefficients of Investments p.c. between 2009 and 2011. SE(Job Yrs) is the standard errors of Job Years calculated via the Delta Method. Costs per Job Year equal 100'000/Job Years.

${ }^{*} p<0.10,{ }^{* *} p<0.05,{ }^{* * *} p<0.01$. 
Acconcia et al., 2014; Dupor and Mehkari, 2016) and weight the counties by their labor force population in the estimation. ${ }^{29}$ Introducing weights leads to a slightly smaller estimate for the number of job years created, but it remains well within the range of estimates reported in Table 2. In row (3) the standard errors are clustered at the level of 94 labor market regions (Raumordnungsregion) to account for the possibility of a local correlation or errors beyond county borders. Doing so leaves the standard errors almost unchanged. Next, we split the sample according to whether the counties were part of former West or East Germany. The results in rows (4) and (5) suggest that the employment effects are strong in West German counties but negligible in the East. This result is plausible given that the backlog of public buildings in need of renovation is likely to be low in the East due to the numerous infrastructure investment programs implemented after reunification. In this case schools should also be a weaker predictor of investments in East Germany than in the West, which is confirmed by the lower Shea Partial $R^{2}$ for the East German sample. Finally, row (6) estimates the employment effects for employees older than 25 years of age to account for the potential concern that counties with a high number of schools are populated by a relatively young labor force with potentially distinct labor market dynamics. Despite excluding the part of the labor force with the most elastic labor supply, economically and statistically significant effects remain.

The second set of robustness checks modifies the instrumental variable strategy. In row (7) the two instruments used in the main specification - the number of primary and secondary schools and the number of academic high schools - are replaced by the number of schools within each of the six school types included in the latter two categories (see Appendix A.2 for details). Conversely, in row (8) the aggregated number of schools across all school types is used as the only instrument. While only the disaggregated number of schools yields statistically significant employment effects, the job year estimates of both alternative specifications of the instruments are very close to the baseline specification. ${ }^{30}$ The focus of the investment program was on renovating school buildings so that old schools are expected to constitute a particularly good instrument

\footnotetext{
${ }^{29}$ The number of papers in the literature that do and do not weight observations by their population are seemingly roughly equal. Other works that, like this paper, abstain from using weights in their main specifications are those by Nakamura and Steinsson (2014), Wilson (2012), and Suárez Serrato and Wingender (2016).

${ }^{30}$ The statistically insignificant result obtained when using the aggregate number of schools as the only instrument may be due to a weak first stage as indicated by the relatively small Shea Partial $R^{2}$ of this specification. This thus highlights the importance of distinguishing between small and large schools.
} 
provided that they persist over time. We test this conjecture in rows (9) and (10) by instrumenting, separately for West and East Germany, infrastructure investments via the number of primary and secondary schools and the number of academic high schools in 1995, the earliest date for which this data is publicly available. The results for West Germany are the same as in the main specification, and the Shea Partial $R^{2}$ indicates that schools in 1995 are a strong instrument for investments. For East Germany, the estimates are very noisy, possibly reflecting the extensive renovation and regional restructuring programs in the wake of reunification, which manifest themselves in lesser needs for renovations as well as low persistence of the number of schools (as shown in Figure 5 in Appendix B.3). Row (11), in turn, rules out the concern that having a growing number of schools reflects a healthy local economy by restricting the sample to those counties, for which the total number of schools in 2008 is weakly less than in 1995. Doing so leaves the empirical findings unchanged.

The third set of robustness checks explores whether altering the extensive set of control variables of the main specification leads to different empirical results. In row (12), we verify that controlling for short-time work, a sizable part of the German stimulus package, does not affect the empirical estimates. ${ }^{31}$ Next, we investigate whether the results are driven by industry-specific shocks that are, for some indeterminate reason, correlated with the instruments. To this end, row (13) includes quarterly "Bartik shocks" as an additional control variable (Bartik, 1991). ${ }^{32}$ This specification only includes data from 2009 onwards, because the employment data at the two-digit sector level is only available starting in 2008 and because one year of data is needed to compute the shocks. The employment differences in this specification are thus estimated relative to employment in Q1 2009. Row (14) uses an alternative approach to account for industry specific shocks. Here, the employment shares within each of the main sectors of the economy-agriculture, manufacturing, and construction (the share in services serves

\footnotetext{
${ }^{31}$ Short-time work is an employment subsidy paid by the German employment agency (Bundesagentur für Arbeit) to workers who are idle due to a temporary drop in demand below output potential. Firms have to request the subsidy for their employees, the requirements of which were loosened during the crisis resulting in a sharp increase in the number of workers receiving short-time work benefits (see, e.g., Burda and Hunt, 2011, for a detailed description of the policy). We control for short-time work using the full-time work equivalents of short-time workers. The data is published at quarterly frequency by the German employment agency.

${ }^{32}$ Bartik shocks are defined as a county's predicted employment level if its employment in each two-digit industry would have grown at the same rate as employment within this industry across all the remaining counties. Formally, the Bartik shock $b_{c, t}$ of county $c$ on quarterly date $t$ is given by $b_{c, t}=\sum_{\mathbf{s} \in 2 \text {-digit industries }}\left[\left(e_{-c, t, s}-e_{-c, t-4, s}\right) / e_{-c, t-4, s}\right] \times e_{c, t-4, s}$, where $e_{-c, t, s}\left(e_{c, t, s}\right)$ is employment in industry $s$ on date $t$ in all counties other than $c$ (in county $c$ ).
} 
as the baseline) - measured in 2008 are interacted with date fixed effects, allowing for very flexible, date-specific shocks correlated with the industry structure. Neither of the ways of controlling for industry-specific shocks affects the empirical results. The remaining four specifications explore alternative ways to control for plausible correlates of the number of schools. Row (15) includes more extensive controls for the age structure by adding the share of the population within the age brackets of 25 to 50 years of age and 50 to 65 years of age to the set of country characteristics that are interacted with date fixed effects. Row (16) adds all of these age brackets (including the school-age population between 6 and 18 years of age) separately for each sex. The final two specifications introduce other means of controlling for population density. Instead of the interactions of date, state, and the value of the urbanization index, we add date fixed effects at the state level as well as counties' area per capita interacted with date fixed effects to the set of covariates in row (17). Row (18) also adds the square of area per capita. Each of these alternative specifications yields estimates of employment gains larger than the ones from the baseline specification.

We relegate additional robustness checks to Appendix C. Appendix C.1 rules out the possible concern that the variation in countercyclical investments may over- or understate the true differences in total fiscal investments if the stimulus funds lead to crowding out or crowding in, respectively, of other regional public investments. ${ }^{33}$ Using balance sheet data on counties' budgets, we show that counties' total investment expenditures per euro of stimulus investments are on average at least as large as counties' total investment grants per euro of stimulus investments. This suggests that stimulus investments lead to crowding in of other investments rather than to crowding out. Appendix C.2 shows that the estimated employment and unemployment effects do not change significantly when they are estimated relative to average employment or average unemployment between 2007 and 2008 instead of relative to Q4 2008. Appendix C.3 shows that collapsing the empirical model (1) into a cross-sectional specification yields the same estimates of job years or reductions in unemployment years as the dynamic models in Tables 2 and 3.

\footnotetext{
${ }^{33}$ Federal transfers for investments could have been crowded out if the stimulus funds had been used to finance projects that had already been planned. However, the stimulus bill explicitly prohibited the financing of projects that had already been budgeted. Federal transfers would have lead to crowding in of local public funds if local governments had decided to add other infrastructure investments to the one financed by the stimulus bill (e.g., using communal funds to add a new parking lot to a school renovated using stimulus funds).
} 


\section{Conclusion}

Since the onset of the Great Recession, the effectiveness of fiscal policy in boosting economic growth and employment has received renewed attention from academic economists and policy makers alike. While there is new theoretical and empirical evidence concerning the macroeconomic conditions under which fiscal policy may be effective in general, the evidence regarding which particular types of policies are successful in fostering growth and increasing jobs is still scarce. ${ }^{34}$ The contribution of this paper is to show that infrastructure investment programs can increase employment quickly and cost-effectively in the short run. Infrastructure investments can thus be a viable tool to counteract an economic slowdown.

Nevertheless, the effectiveness of investment programs may crucially depend on their design. The German investment program studied here placed particular emphasis on financing the renovation of buildings. Building construction is an industry characterized by low levels of specialization and low geographic concentration compared with, for example, highway construction. Moreover, the stimulus bill emphasized projects implemented at the local level and mandated a tight deadline for the completion of projects. Each of these factors may have contributed to the effectiveness of the program in creating jobs at the regional level. One question for future research that originates from our work is hence whether there are specific characteristics of investment programs that make them more or less effective.

A related question is how the effectiveness of public investments in creating jobs compares with the job creation of other major tools of fiscal policy, like direct transfers to households or tax cuts. Although Parker et al. (2013) show that government transfers have a high marginal propensity to consume, there is little evidence on how this translates into employment gains in the short run. However, given that job creation is a major policy objective, it is important for policy makers to know which of their tools are most suitable for achieving it. By evaluating the effectiveness of one specific policy, countercyclical investments, this paper takes a first step towards answering this question. More research is needed to inform policy makers about the employment effects of other policy tools at their disposal.

\footnotetext{
${ }^{34}$ For recent theoretical contributions regarding the effects of fiscal policy on output or employment, see, for example, Eggertsson and Krugman (2012), Nakamura and Steinsson (2014), or Rendahl (forthcoming).
} 


\section{References}

Acconcia, Antonio, Giancarlo Corsetti, and Saverio Simonelli, "Mafia and Public Spending: Evidence on the Fiscal Multiplier from a Quasi-Experiment," American Economic Review, 2014, 104 (7), 2185-2209.

Angrist, Joshua David and Jörn-Steffen Pischke, Mostly Harmless Econometrics: An Empiricist's Companion, Princeton: Princeton University Press, 2009.

Auerbach, Alan J. and Yuriy Gorodnichenko, "Measuring the Output Responses to Fiscal Policy," American Economic Journal: Economic Policy, 2012, 4 (2), 1-27.

Bartik, Timothy J., Who Benefits from State and Local Economic Development Policies? Books from Upjohn Press, W.E. Upjohn Institute for Employment Research, 1991.

Becker, Gary, "Infrastructure in a Stimulus Package," 2009.

Beetsma, Roel and Massimo Giuliodori, "The Effects of Government Purchases Shocks: Review and Estimates for the EU," Economic Journal, 2011, 121 (550), F4-F32.

Blanchard, Olivier Jean and Roberto Perotti, "An Empirical Characterization of the Dynamic Effects of Changes in Government Spending and Taxes on Output," Quarterly Journal of Economics, 2002, 117 (4), 1329-1368.

Buchheim, Lukas, Matthias Wilhelm, and Martin Watzinger, "Investment in Photovoltaics and Job Creation: Evidence from a Billion Dollar Program," mimeo, 2016.

Bundesministerium der Finanzen, "Haushaltsplan 2011," 2011.

_ , "Haushaltsplan 2012," 2012.

_ , "Haushaltsplan 2013," 2013.

_ , "Monatsbericht des BMF Juli 2013," 2013.

Bundesministerium für Wirtschaft und Technologie, "Konjunktur- und wachstumspolitische Maßnahmen der Bundesregierung in der Wirtschafts- und Finanzkrise," 2011.

Bundesrechnungshof, "Bericht nach § 99 BHO über die Auswirkungen der Vergabeerleichterungen des Konjunkturpakets II auf die Beschaffung von Bauleistungen und freiberuflichen Leistungen bei den Bauvorhaben des Bundes," 2012.

Burda, Michael C. and Jennifer Hunt, "What Explains the German Labor Market Miracle in the Great Recession," Brookings Papers on Economic Activity, 2011, 42 (1), 273-335. 
Chodorow-Reich, Gabriel, Laura Feiveson, Zachary Liscow, and William Gui Woolston, "Does State Fiscal Relief During Recessions Increase Employment? Evidence from the American Recovery and Reinvestment Act," American Economic Journal: Economic Policy, 2012, 4 (3), 118-145.

Clemens, Jeffrey and Stephen Miran, "Fiscal Policy Multipliers on Subnational Government Spending," American Economic Journal: Economic Policy, 2012, 4 (2), 46-68.

Conley, Timothy G. and Bill Dupor, "The American Recovery and Reinvestment Act: Solely a Government Jobs Program?," Journal of Monetary Economics, 2013, $60(5), 535-549$.

Corbi, Raphael, Elias Papaioannou, and Paolo Surico, "Federal Transfer Multipliers. Quasi-Experimental Evidence from Brazil," NBER Working Paper, 2014, 20751.

Dube, Arindrajit, Ethan Kaplan, and Ben Zipperer, "Excess Capacity and Heterogeneity in the Fiscal Multiplier: Evidence from the Obama Stimulus Package," Working Paper, 2014.

Dupor, Bill, "Local and Aggregate Fiscal Policy Multipliers," Federal Reserve Bank of St. Louis Working Paper, 2016, 2016-004.

_ and M. Saif Mehkari, "Schools and Stimulus," Working Paper, 2015.

_ and _, "The 2009 Recovery Act: Stimulus at the Extensive and Intensive Labor Margins," European Economic Review, 2016, 85, 208-228.

_ and Peter B. McCrory, "A Cup Runneth Over: Fiscal Policy Spillovers from the 2009 Recovery Act," Federal Reserve Bank of St. Louis Working Paper, 2015, 2014-029.

Eggertsson, Gauti B. and Paul Krugman, "Debt, Deleveraging, and the Liquidity Trap: A Fisher-Minsky-Koo Approach," Quarterly Journal of Economics, 2012, 127 (3), 1469-1513.

Farhi, Emmanuel and Iván Werning, "Fiscal Multipliers: Liquidity Traps and Currency Unions," in John B. Taylor and Harald Uhlig, eds., Handbook of Macroeconomics, Vol. 2, Elsevier, 2016, pp. 2417-2492.

Feyrer, James and Bruce Sacerdote, "Did the Stimulus Stimulate? Real Time Estimates of the Effects of the American Recovery and Reinvestment Act," NBER Working Paper, 2011, 16759.

Fuchs-Schündeln, Nicola and Tarek A. Hassan, "Natural Experiments in Macroe- 
conomics," in John B. Taylor and Harald Uhlig, eds., Handbook of Macroeconomics, Vol. 2, Elsevier, 2016, pp. 923-1012.

Garin, Andy, "Putting America to Work, Where? The Limits of Infrastructure Construction as a Locally-Targeted Employment Policy," Taubman Center Working Paper, 2016, 2016-01.

Glaeser, Edward, "If You Build It... Myths and Realities about America's Infrastructure Spending," City Journal, 2016, Summer 2016.

Green, Daniel, Brian Melzer, Johnathan A. Parker, and Arcenis Rojas, "Accelerator or Brake? Microeconomic Estimates of the 'Cash for Clunkers' and Aggregate Demand," NBER Working Paper, 2016, 22878.

IMF, World Economic Outlook, October 2014: Legacies, Clouds, Uncertainties, Vol. 2014,Oct, Washington and DC: International Monetary Fund, 2014.

Kamps, Christophe, "The Dynamic Effects of Public Capital: VAR Evidence for 22 OECD Countries," International Tax and Public Finance, 2005, 12 (4), 533-558.

Leduc, Sylvain and Daniel Wilson, "Roads to Prosperity or Bridges to Nowhere? Theory and Evidence on the Impact of Public Infrastructure Investment," NBER Macroeconomics Annual, 2013, 27 (1), 89-142.

- and _, "Infrastructure Spending as Fiscal Stimulus: Assessing the Evidence," Review of Economics and Institutions, 2014, 5 (1), 2-24.

_ and _, "Are State Governments Roadblocks to Federal Stimulus? Evidence on the Flypaper Effect of Highway Grants in the 2009 Recovery Act," Federal Reserve Bank of San Francisco Working Paper, 2015, 2013-16.

Leeper, Eric M., Todd B. Walker, and Shu-Chun S. Yang, "Government Investment and Fiscal Stimulus," Journal of Monetary Economics, 2010, 57 (8), 1000-1012.

Mian, A. and A. Sufi, "The Effects of Fiscal Stimulus: Evidence from the 2009 Cash for Clunkers Program," Quarterly Journal of Economics, 2012, 127 (3), 1107-1142.

Nakamura, Emi and Jón Steinsson, "Fiscal Stimulus in a Monetary Union: Evidence from US Regions," American Economic Review, 2014, 104 (3), 753-792.

OECD, "The Effectiveness and Scope of Fiscal Stimulus," in OECD, ed., OECD Economic Outlook, Interim Report March 2009, Paris: OECD Publishing, 2009.

Owyang, Michael T., Valerie A. Ramey, and Sarah Zubairy, "Are Government Spending Multipliers Greater during Periods of Slack? Evidence from TwentiethCentury Historical Data," American Economic Review, 2013, 103 (3), 129-134.

Parker, Jonathan A., "On Measuring the Effects of Fiscal Policy in Recessions," 
Journal of Economic Literature, 2011, 49 (3), 703-718.

_, Nicholas S. Souleles, David S. Johnson, and Robert McClelland, "Consumer Spending and the Economic Stimulus Payments of 2008," American Economic Review, 2013, 103 (6), 2530-2553.

Pereira, Alfredo M., "Is All Public Capital Created Equal?," Review of Economics and Statistics, 2000, 82 (3), 513-518.

Perotti, Roberto, "Public Investment: Another (Different) Look," IGIER Working Paper, 2004, 27\%.

Porcelli, Francesco and Riccardo Trezzi, "Reconstruction Multipliers," FEDS Working Paper, 2014, 2014-79.

Ramey, Valerie A., "Can Government Purchases Stimulate the Economy?," Journal of Economic Literature, 2011, 49 (3), 673-685.

_ , "Identifying Government Spending Shocks: It's all in the Timing," Quarterly Journal of Economics, 2011, 126 (1), 1-50.

Rendahl, Pontus, "Fiscal Policy in an Unemployment Crisis," Review of Economic Studies, forthcoming.

Sanderson, Eleanor and Frank Windmeijer, "A Weak Instrument F-Test in Linear IV Models with Multiple Endogenous Variables," Journal of Econometrics, 2016, 190 (2), 212-221.

Shoag, Daniel, "The Impact of Government Spending Shocks: Evidence on the Multiplier from State Pension Plan Returns," Harvard Kennedy School Working Paper, 2010.

Slansky, Friederike, "Bund-Länder-Konjunkturprogramm - Wo kommen die Finanzhilfen an?," Nationalatlas Aktuell, 2010, 4.

Stock, James H. and Motohiro Yogo, "Testing for Weak Instruments in Linear IV Regression," Identification and Inference for Econometric Models: Essays in Honor of Thomas Rothenberg, 2005.

Suárez Serrato, Juan Carlos and Philippe Wingender, "Estimating Local Fiscal Multipliers," NBER Working Paper, 2016, 22425.

Summers, Lawrence H., "Summary of Testimony to House Budget Committee, September 9th 2008," 2008.

Wilson, Daniel J., "Fiscal Spending Jobs Multipliers: Evidence from the 2009 American Recovery and Reinvestment Act," American Economic Journal: Economic Policy, 2012, 4 (3), 251-282. 


\section{Appendix (for online publication)}

\section{A Appendix to Section 3: Data and Identifying Variation}

\section{A.1 Data Sources and Definitions}

Table 7: Data Sources and Definitions

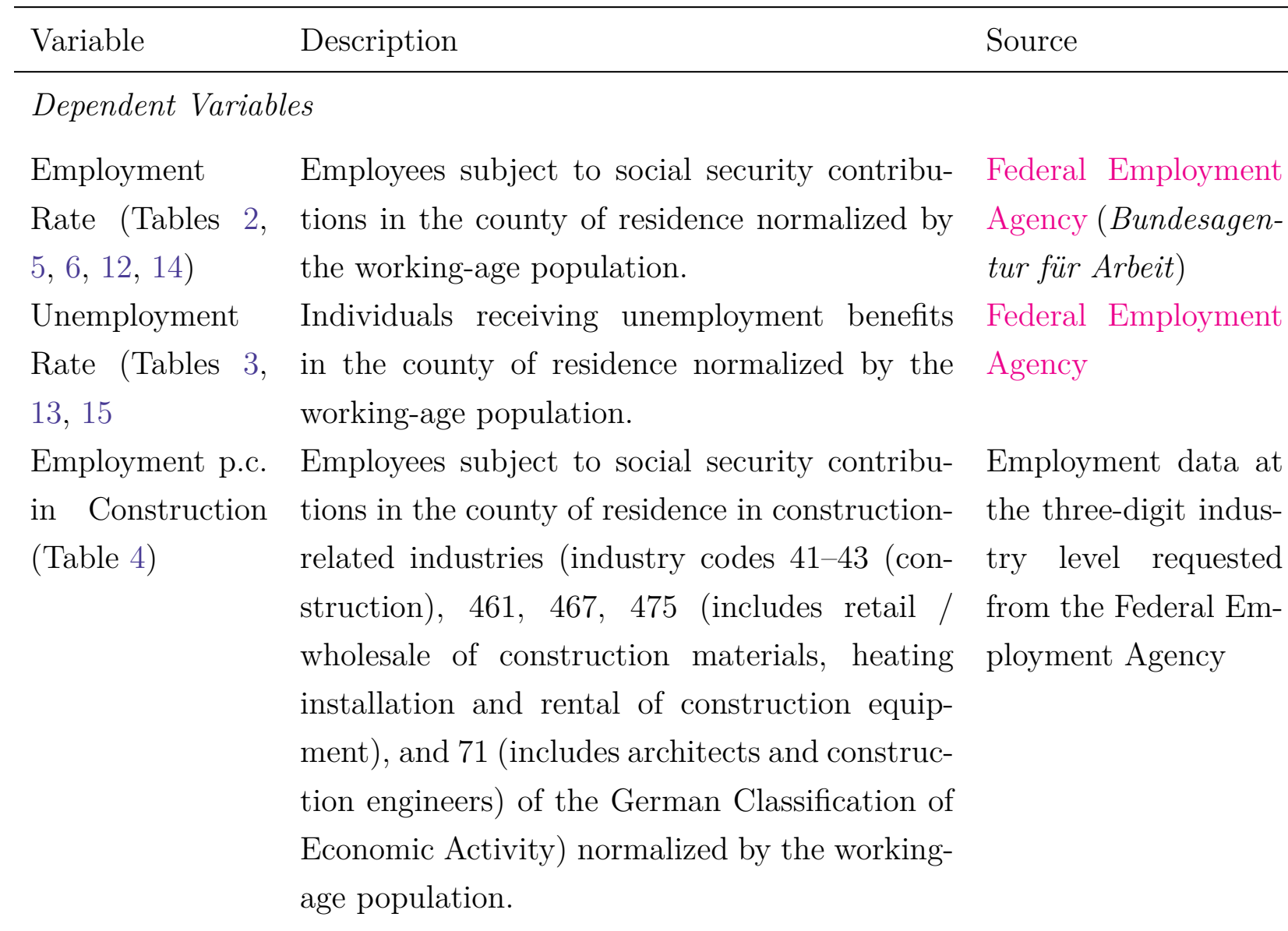

Employment p.c. Employees subject to social security contribuin Non-Tradables tions in the county of residence in local, non(Table 4) tradable industries (industry codes 45-47 except 461, 467, 475 (wholesale and retail), 55-56 (hotel and restaurant industry) of the German Classification of Economic Activity) normalized by the working-age population.

Employment data at the three-digit industry level requested from the Federal Employment Agency 


\begin{tabular}{|c|c|c|}
\hline Variable & Description & Source \\
\hline $\begin{array}{l}\text { Employment p.c. } \\
\text { in Other Indus- } \\
\text { tries (Table 4) }\end{array}$ & $\begin{array}{l}\text { Employees subject to social security contribu- } \\
\text { tions in the county of residence in all the indus- } \\
\text { tries not included in "Construction" and "Non- } \\
\text { Tradables" normalized by the working-age pop- } \\
\text { ulation. }\end{array}$ & $\begin{array}{l}\text { Employment data at } \\
\text { the three-digit indus- } \\
\text { try level requested } \\
\text { from the Federal Em- } \\
\text { ployment Agency }\end{array}$ \\
\hline Investment & Total investment grants (Zuweisungen, & German Statistical \\
\hline $\begin{array}{l}\text { Grants } \quad \text { p.c. } \\
\text { (Table 11) }\end{array}$ & $\begin{array}{l}\text { Zuschüsse für Investitionsförderungen) from } \\
\text { higher layers of government to a county and } \\
\text { all of its municipalities (normalized by the } \\
\text { working-age population). Yearly data. This } \\
\text { data is not available for all the states due to } \\
\text { changes in accounting rules. }\end{array}$ & $\begin{array}{l}\text { Office (Destatis), } \\
\text { balance sheet data } \\
\text { of counties and mu- } \\
\text { nicipalities } \quad \text { (code } \\
346-21-4)\end{array}$ \\
\hline $\begin{array}{ll}\text { Investment } & \text { Ex- } \\
\text { penditures } & \text { p.c. } \\
\text { (Table 11) } & \end{array}$ & $\begin{array}{l}\text { Total invesment expenditures (Ausgaben für } \\
\text { Sachinvestitionen) a county and all of its munic- } \\
\text { ipalities (normalized by the working-age popu- } \\
\text { lation). Yearly data. This data is not available } \\
\text { for all the states due to changes in accounting } \\
\text { rules. }\end{array}$ & $\begin{array}{l}\text { German Statistical } \\
\text { Office, balance sheet } \\
\text { data of counties and } \\
\text { municipalities (code } \\
346-42-4)\end{array}$ \\
\hline Working-Age & The population of working age (between 15 & Statistical \\
\hline Population & $\begin{array}{l}\text { and } 65 \text { years of age) in } 2008 \text {. In our analysis, } \\
\text { most variables are normalized by the working- } \\
\text { age population (indicated by "p.c." in the vari- } \\
\text { able name). }\end{array}$ & $\begin{array}{lr}\text { Office, } & \text { population } \\
\text { statistics } & \text { (code } \\
173-21-4) & \end{array}$ \\
\hline
\end{tabular}




\begin{tabular}{|c|c|c|}
\hline Variable & Description & Source \\
\hline \multicolumn{3}{|c|}{ Countercyclical Investments and Instruments } \\
\hline $\begin{array}{l}\text { Investments p.c. } \\
\text { in } € 100 ' 000 \text { (all } \\
\text { tables except Ta- } \\
\text { ble 8) }\end{array}$ & $\begin{array}{l}\text { The sum of countercyclical investments between } \\
2009 \text { and } 2011 \text { within a county and all of its } \\
\text { municipalities. We aggregate investments from } \\
\text { the project lists using county and municipality } \\
\text { identifiers. Projects at the state level (without } \\
\text { a county or municipality identifier) are omitted. }\end{array}$ & $\begin{array}{l}\text { Project lists of the } \\
\text { Federal Department } \\
\text { of the Treasury ob- } \\
\text { tained via personal } \\
\text { communication }\end{array}$ \\
\hline 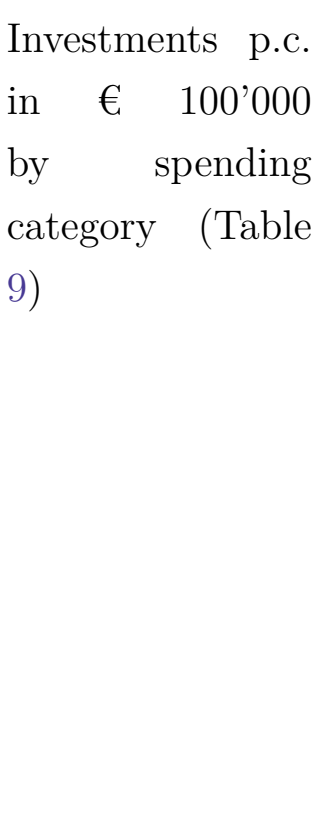 & $\begin{array}{l}\text { The sum of countercyclical investments be- } \\
\text { tween } 2009 \text { and } 2011 \text { into schools, universi- } \\
\text { ties, hospitals, and all the remaining types of } \\
\text { projects. Investments are allocated to project } \\
\text { types based on the project descriptions using } \\
\text { a textual matching procedure. This is possible } \\
\text { for all the states but Saxony-Anhalt, where the } \\
\text { project descriptions are not sufficiently detailed. } \\
\text { The project descriptions are not reported in the } \\
\text { project lists obtained from the federal govern- } \\
\text { ment described above. For this reason, the ex- } \\
\text { ercise in Table } 9 \text { uses project lists obtained from } \\
\text { the states. }\end{array}$ & $\begin{array}{l}\text { Project lists of the } \\
\text { states obtained from } \\
\text { the responsible ad- } \\
\text { ministrative unit of } \\
\text { the states (in most } \\
\text { cases the Department } \\
\text { of the Treasury or the } \\
\text { Department of Com- } \\
\text { merce) via personal } \\
\text { communication }\end{array}$ \\
\hline $\begin{array}{l}\text { Number } \text { of } \\
\text { School / Other } \\
\text { Projects } \quad \text { (Table } \\
9 \text { ) }\end{array}$ & $\begin{array}{l}\text { The number of investment projects classified as } \\
\text { school related projects as well as all the re- } \\
\text { maining projects (normalized by the working- } \\
\text { age population). See above for details. }\end{array}$ & $\begin{array}{l}\text { Project lists of the } \\
\text { states (see above) }\end{array}$ \\
\hline
\end{tabular}




\begin{tabular}{lll}
\hline Variable & Description & Source \\
\hline Schools (all ta- & The number of schools within a county mea- German Statistical \\
bles) & sured in 2008 (or 1995 in Table 6). The official Office, school statis- \\
& statistics provide the numbers of schools for ten tics (code 192-32-4) \\
& different school types. Based on the size of the \\
& school types, these numbers are aggregated into \\
& two categories to generate the main instruments \\
& Academic High Schools p.c. and Primary and \\
& Secondary Schools p.c. See Section A.2 for de- \\
& tails.
\end{tabular}

Control Variables

Population The ratio of the working-age population in any

Growth (all the given year and the working-age population in tables except 2008. Yearly data.

Tables 8 and 11)

Urbanization Index (all the tables except Tables 8 and 11)

Employment

Shares by Education (all the tables except Tables 8 and 11) besiedelte ländliche Kreise) to the total number of employees (also denoted "Empl. Share with College" in Tables 1, 14, 15) and the ratio of employees with vocational training to the total number of employees (also
A four-point urbanization index (sied- Federal Office for lungsstrukturelle Kreistypen) with the cate- Building and Regories metropolitan area (kreisfreie Großstadt), gional Planning city (städtischer Kreis), rural county with (Bundesamt für towns (ländlicher Kreis mit Verdichtungsan- Bauwesen und Rausätzen), little populated rural counties (dünn mordnung)

The ratio of employees with a university degree denoted "Empl. Share with Vocational Tr." in Tables $1,14,15)$ as of 2008 . The baseline is the share of employees with a lower education than vocational training.

Federal Office for

\section{Agency} Federal Employment Agency

German Statistical Office, population statistics (code 173-21-4) 


\begin{tabular}{|c|c|c|}
\hline Variable & Description & Source \\
\hline $\begin{array}{l}\text { Share School- } \\
\text { Age Population } \\
\text { (all the tables } \\
\text { except Tables } 8 \\
\text { and 11) }\end{array}$ & $\begin{array}{l}\text { The ratio of the school-age population (between } \\
6 \text { and } 18 \text { years of age) to the working-age pop- } \\
\text { ulation as of } 2008 \text {. }\end{array}$ & $\begin{array}{lr}\text { German } & \text { Statistical } \\
\text { Office, } & \text { population } \\
\text { statistics } & \text { (code } \\
173-21-4) & \end{array}$ \\
\hline $\begin{array}{l}\text { Universities p.c. } \\
\text { (all the tables ex- } \\
\text { cept Tables } 8 \text { and } \\
\text { 11) }\end{array}$ & $\begin{array}{l}\text { The number of PhD-granting universities with } \\
\text { at least } 1000 \text { students within a county as of } 2015 \\
\text { (download date of the data: February 2015) }\end{array}$ & $\begin{array}{l}\text { University statis- } \\
\text { tics of the German } \\
\text { Rectors' Conference } \\
\text { (Hochschulrektoren- } \\
\text { konferenz) }\end{array}$ \\
\hline $\begin{array}{l}\text { Hospitals p.c. } \\
\text { (all the tables } \\
\text { except Tables } 8 \\
\text { and 11) }\end{array}$ & $\begin{array}{l}\text { The number of hospitals within a county as of } \\
2008 \text {. }\end{array}$ & $\begin{array}{lr}\text { German } & \text { Statisti- } \\
\text { cal Office, } & \text { hospital } \\
\text { statistics } & \text { (code } \\
\text { 188-61-4) } & \end{array}$ \\
\hline $\begin{array}{l}\text { Short-time work } \\
\text { (Table } 6 \text { ) }\end{array}$ & $\begin{array}{l}\text { The ratio of short-time workers at each quar- } \\
\text { terly date to the working-age population in } \\
2008 \text {. The measure of short-time work is the } \\
\text { full-time equivalent (Beschäftigungsäquivalent) } \\
\text { of short-time workers due to cyclical reasons } \\
\text { (konjunkturelle Kurzarbeit). }\end{array}$ & $\begin{array}{l}\text { Federal Employment } \\
\text { Agency }\end{array}$ \\
\hline $\begin{array}{l}\text { Bartik shocks } \\
\text { (Table 6) }\end{array}$ & $\begin{array}{l}\text { See Footnote } 32 \text { for the formal definition of Bar- } \\
\text { tik shocks } b_{c, t} \text {. The shock } b_{c, t} \text { is normalized by } \\
\text { the working-age population in } 2008 \text {. }\end{array}$ & $\begin{array}{l}\text { Employment data at } \\
\text { the three-digit indus- } \\
\text { try level requested } \\
\text { from the Federal Em- } \\
\text { ployment Agency }\end{array}$ \\
\hline $\begin{array}{l}\text { Industry Struc- } \\
\text { ture Controls } \\
\text { (Table 6) }\end{array}$ & $\begin{array}{l}\text { A vector of three variables, all as of Q1 2008: } \\
\text { the share of employees in agriculture (industry } \\
\text { codes 01-03), the share of employees in manu- } \\
\text { facturing (industry codes } 05-39 \text { ), and the share } \\
\text { of employees in construction (industry codes } \\
41-43 \text { ). The omitted category is the share of } \\
\text { employees in services (industry codes } 45-95 \text { ). }\end{array}$ & $\begin{array}{l}\text { Employment data at } \\
\text { the three-digit indus- } \\
\text { try level requested } \\
\text { from the Federal Em- } \\
\text { ployment Agency }\end{array}$ \\
\hline
\end{tabular}




\begin{tabular}{|c|c|c|}
\hline Variable & Description & Source \\
\hline Age Structure & The ratio of individuals between 25 and 50 years & German Statistical \\
\hline $\begin{array}{l}\text { Controls (Table } \\
6)\end{array}$ & $\begin{array}{l}\text { of age to the working-age population and the } \\
\text { ratio of individuals between } 50 \text { and and } 65 \text { years }\end{array}$ & $\begin{array}{lr}\text { Office, } & \text { population } \\
\text { statistics } & \text { (code }\end{array}$ \\
\hline & $\begin{array}{l}\text { of age to the working-age population, both as of } \\
\text { 2008. Either aggregated or separate by sex. }\end{array}$ & $173-21-4)$ \\
\hline $\begin{array}{l}\text { Area p.c. (Table } \\
6)\end{array}$ & The total area of a county in $\mathrm{km}^{2}$ as of 2008 . & $\begin{array}{l}\text { German Statistical } \\
\text { Office, area statistics } \\
\text { (code } 171-01-4)\end{array}$ \\
\hline
\end{tabular}

\section{A.2 School Types and Sizes in Germany}

There are several types of schools in Germany, both because students typically start specializing in fifth grade and because the school system is organized at the state level, so that there is some heterogeneity across states. In general, though, all students attend a primary school (Grundschule) first, where children are allocated to schools based on the school district. After primary school, students (and their parents) choose between a number of secondary schools. Two types of secondary schools, Hauptschule and Realschule, prepare students for vocational training, where the former is more focused on manual work, while the latter is more focused on administrative work. If students intend to go to college, they have to pass A-levels (Abitur), for which they need to attend an Academic High Schools (Gymnasium). Furthermore, in some states there are schools that combine Hauptschule and Realschule (called Schulen mit mehreren Bildungsgängen in the school statistics), the first two types of secondary schools, as well as schools that combine all three types of secondary schools (so called Comprehensive Schools or, in German, Gesamtschulen). The school statistics also include five minor school types, namely preschools (Vorschule), a specific type of middle school (schulartenunabhängige Orientierungsstufe), Waldorf schools (Waldorfschule, the most prevalent type of private schools), and evening schools (Abendschule und Kollegs).

For the empirical analyses, we organize the data on schools as follows. Since some states introduced the Schulen mit mehreren Bildungsgängen to combine the non-academic tracks of secondary schools, we add this school type to the number of secondary schools with administrative focus and call the resulting class of schools Secondary Schools - administrative. Furthermore, we combine the five minor school 
Table 8: Summary Statistics: Students per School

\begin{tabular}{|c|c|c|c|c|}
\hline & \multicolumn{4}{|c|}{ Students per School (by School Type) } \\
\hline & \multirow{2}{*}{$\begin{array}{l}\text { throughout } \\
\text { Germany }\end{array}$} & \multicolumn{3}{|c|}{ Percentile of County Avg } \\
\hline & & $\mathrm{P} 10$ & $\mathrm{P} 50$ & P90 \\
\hline & \multicolumn{4}{|c|}{ Panel A: Primary and Secondary Schools } \\
\hline Primary \& Secondary Schools & 196 & 139 & 196 & 272 \\
\hline Primary Schools (Grundschule) & 180 & 128 & 179 & 237 \\
\hline Secondary Schools - manual work (Hauptschule) & 194 & 110 & 199 & 317 \\
\hline Secondary Schools - administrative (Realschule) & 404 & 193 & 477 & 710 \\
\hline \multirow[t]{2}{*}{ Secondary Schools - others } & 102 & 56 & 110 & 198 \\
\hline & \multicolumn{4}{|c|}{ Panel B: Academic High Schools } \\
\hline Academic High Schools & 788 & 496 & 834 & 1139 \\
\hline Academic High Schools (Gymnasium) & 807 & 518 & 842 & 1154 \\
\hline Comprehensive Schools (Gesamtschule) & 697 & 162 & 791 & 1206 \\
\hline
\end{tabular}

Notes. This table reports the number of students per school by school type. This statistic is reported as the nationwide average given by the ratio of the total number of students and the total number of schools throughout Germany, as well as by its 10th, 50th, and 90th percentile across counties. See the text for a description of the types of schools.

types within one category called Secondary Schools - others. Finally, as there is a clear dichotomy among all the school types with respect to their size, we aggregate all the school types into two groups: "academic high schools" (the sum of Comprehensive Schools and Academic High Schools, which both offer A-levels) and Primary and Secondary Schools (the remaining school types).

Table 8 provides statistics on the distribution of school size within the school types. Specifically, it reports the average number of students per school for each major school type throughout Germany, as well as the 10th, 50th, and 90th percentile of the number of students per schools across counties. There is a clear size difference across school types. On the one hand, Primary Schools, Secondary Schools - manual work, and Secondary Schools - others have, on average, less than 200 students, and have a narrow distribution of averages across counties with the 10th percentile larger than 100 students per school, and the 90th percentile smaller than 320 students per school. Secondary Schools - administrative have 404 students on average and are thus slightly larger than the remaining school types within the group of Primary and Secondary 
Schools. Nevertheless, the 90th percentile of Secondary Schools - administrative is smaller than the median number of students per school in Academic High Schools (Gymnasium) and Comprehensive Schools. These schools are, on average, about four times as large as the average "primary and secondary school."

\section{B Appendix to Section 5: Identification Strategy}

This section reports additional results supporting the identification strategy. Section B.1 uses supplemental data on investments projects that entails the project descriptions to show that the number of schools explains school related investments. Section B.2 presents the complete system of first stage equations of the main specification reported in column (4) of Tables 2 and 3. Section B.3 shows that the number of schools in the former West German states is more persistent than in the former East German states.

\section{B.1 The Number of Schools Predominantly Predicts School Investments}

In this section, we show that the number of schools indeed predominantly predicts investments into schools (as opposed to investments that had other purposes). Projects, and, hence, investments, can be linked to their purpose via the project descriptions that states had to communicate to the federal government. These descriptions are missing in the complete list of investment projects obtained from the Federal Department of the Treasury, which is the source of the investment data in the main part of the paper. We were able to obtain project level data from a second source - the administrative units of the states responsible for the distribution of funds - that includes these descriptions for all the states with the exceptions of Bremen and Saxony-Anhalt. For the states available, these project lists contain 96 percent of the projects and 95 percent of investments. Based on this data, we assign the projects to funding lines (projects related to schools, universities, hospitals and all the other types of projects) using a textual matching procedure that applies a bag of words algorithm.

Columns (1) to (5) of Table 9 present the results of regressing the subsets of investments within different funding lines on the instruments as well as the full set of covariates. Apart from the varying dependent variables, we use the same empirical specification as the one underlying column (4) of Table 1, which we reproduce in column (1) of Table 9 for comparison. The results show that the number of schools per capita is strongly correlated with investments in schools. Also, the number of 
Table 9: First Stage: Schools Predict School Investments

\begin{tabular}{|c|c|c|c|c|c|c|c|}
\hline & \multicolumn{5}{|c|}{ Countercyclical Investments p.c. in $€ 100^{\prime} 000$} & \multicolumn{2}{|c|}{ Projects } \\
\hline & $\begin{array}{c}\text { Total } \\
(1)\end{array}$ & $\begin{array}{c}\text { Schools } \\
\quad(2)\end{array}$ & $\begin{array}{c}\text { Universities } \\
(3)\end{array}$ & $\begin{array}{c}\text { Hospitals } \\
\text { (4) }\end{array}$ & $\begin{array}{c}\text { Other } \\
(5)\end{array}$ & $\begin{array}{l}\text { Schools } \\
\text { (6) }\end{array}$ & $\begin{array}{c}\text { Other } \\
(7)\end{array}$ \\
\hline Academic High Schools p.c. & $\begin{array}{l}10.09^{* * *} \\
(2.98)\end{array}$ & $\begin{array}{c}4.51^{* *} \\
(1.75)\end{array}$ & $\begin{array}{c}2.86 \\
(1.81)\end{array}$ & $\begin{array}{l}1.59^{* *} \\
(0.72)\end{array}$ & $\begin{array}{c}1.94 \\
(1.25)\end{array}$ & $\begin{array}{l}1.07^{* *} \\
(0.42)\end{array}$ & $\begin{array}{c}0.16 \\
(0.39)\end{array}$ \\
\hline Primary \& Second. Schools p.c. & $\begin{array}{c}1.53^{* *} \\
(0.65)\end{array}$ & $\begin{array}{l}1.24^{* * *} \\
(0.43)\end{array}$ & $\begin{array}{l}0.88^{* *} \\
(0.34)\end{array}$ & $\begin{array}{c}-0.08 \\
(0.21)\end{array}$ & $\begin{array}{c}-0.23 \\
(0.31)\end{array}$ & $\begin{array}{l}0.45^{* * *} \\
(0.16)\end{array}$ & $\begin{array}{l}0.28^{* * *} \\
(0.10)\end{array}$ \\
\hline Empl. Share w College /100 & $\begin{array}{c}0.71^{* *} \\
(0.34)\end{array}$ & $\begin{array}{c}0.26^{*} \\
(0.14)\end{array}$ & $\begin{array}{l}0.87^{* * *} \\
(0.27)\end{array}$ & $\begin{array}{r}-0.15 \\
(0.13)\end{array}$ & $\begin{array}{r}-0.11 \\
(0.10)\end{array}$ & $\begin{array}{c}0.10^{*} \\
(0.06)\end{array}$ & $\begin{array}{c}0.02 \\
(0.03)\end{array}$ \\
\hline Empl. Share w Vocational Tr. /100 & $\begin{array}{c}-0.10 \\
(0.20)\end{array}$ & $\begin{array}{r}-0.11 \\
(0.13)\end{array}$ & $\begin{array}{c}0.14 \\
(0.11)\end{array}$ & $\begin{array}{c}-0.18^{* *} \\
(0.08)\end{array}$ & $\begin{array}{c}0.17^{* *} \\
(0.08)\end{array}$ & $\begin{array}{l}0.19^{* * *} \\
(0.05)\end{array}$ & $\begin{array}{l}0.09^{* * *} \\
(0.02)\end{array}$ \\
\hline Share School-Age Pop /100 & $\begin{array}{c}0.01 \\
(0.42)\end{array}$ & $\begin{array}{c}0.50^{* *} \\
(0.23)\end{array}$ & $\begin{array}{r}-0.46 \\
(0.30)\end{array}$ & $\begin{array}{r}-0.12 \\
(0.12)\end{array}$ & $\begin{array}{r}-0.06 \\
(0.20)\end{array}$ & $\begin{array}{r}-0.04 \\
(0.09)\end{array}$ & $\begin{array}{r}-0.03 \\
(0.05)\end{array}$ \\
\hline Universities p.c. & $\begin{array}{l}85.19^{* * *} \\
(21.92)\end{array}$ & $\begin{array}{c}8.68 \\
(9.67)\end{array}$ & $\begin{array}{l}77.99^{* * *} \\
(16.93)\end{array}$ & $\begin{array}{r}-6.72 \\
(5.05)\end{array}$ & $\begin{array}{c}3.09 \\
(7.98)\end{array}$ & $\begin{array}{r}-0.56 \\
(2.91)\end{array}$ & $\begin{array}{r}-1.16 \\
(2.68)\end{array}$ \\
\hline Hospitals p.c. & $\begin{array}{c}4.35 \\
(2.95)\end{array}$ & $\begin{array}{c}0.20 \\
(1.22)\end{array}$ & $\begin{array}{c}0.21 \\
(1.27)\end{array}$ & $\begin{array}{c}0.77 \\
(0.81)\end{array}$ & $\begin{array}{c}1.78 \\
(2.57)\end{array}$ & $\begin{array}{c}0.38 \\
(0.40)\end{array}$ & $\begin{array}{r}-0.06 \\
(0.29)\end{array}$ \\
\hline State $\times$ UrbanIndex FE & yes & yes & yes & yes & yes & yes & yes \\
\hline Kleibergen-Paap F & 9.77 & 6.93 & 6.20 & 2.46 & 1.81 & 7.83 & 4.17 \\
\hline Shea Partial $\mathrm{R}^{2}$ & 0.07 & 0.08 & 0.04 & 0.01 & 0.01 & 0.05 & 0.03 \\
\hline Observations & 400 & 384 & 384 & 384 & 384 & 384 & 384 \\
\hline
\end{tabular}

Notes. The dependent variable in column (1), Countercyclical Investments p.c. in €100'000 - Total, is the sum of investments normalized by the working-age population (indicated by "p.c." for "per capita") over the years 2009 to 2011 using the investment data from the main part of the paper (column (1) is identical to column (4) of Table 1). The remaining columns use a subset of the data that entails the project descriptions to classify investment projects according to their purpose. The dependent variables in columns (2) to (5) are the sum of investments in schools, universities, hospitals, and the sum of investments for all the remaining purposes. The dependent variable in column (6) is the number of projects categorized as school related, and the dependent variable in column (7) is the number of all the other projects. The remaining variables and statistics are defined as in Table 1. Academic High Schools p.c. and Primary and Secondary Schools p.c. are the excluded instruments for the Kleibergen-Paap F statistic and the Shea Partial $R^{2}$. The sample is the cross-section of counties as measured in Q4 2008; in columns (2) to (7) the counties within the states Bremen and Saxony-Anhalt drop, as the project descriptions are unavailable for these states. Robust standard errors are in parentheses.

${ }^{*} p<0.10,{ }^{* *} p<0.05, * * * p<0.01$. 
universities is strongly correlated with investments in universities. Only for hospitals investments, the coefficient of the number of hospitals is not statistically significantly different from zero. Also, the significant coefficients of Primary and Secondary Schools p.c., when the dependent variable is investments in universities, and of Academic High Schools p.c., when the dependent variable is investments in hospitals, are not as expected. However, these results may be due to the necessarily imperfect classification procedure based on textual analysis.

In Columns (6) and (7), the dependent variables are the number of school related investment projects and the number of all the other investment projects, respectively. Academic High Schools p.c. and Primary and Secondary Schools p.c. are strongly correlated with the number of school projects and much less so with the number of other projects. Specifically, there are, on average, more than twice as many projects associated with one Academic High School as with one Primary and Secondary School. This finding may contribute to explain why the average total investments per Academic High School are six to seven times as large as total investments per Primary and Secondary School in column (1). ${ }^{35}$

\section{B.2 The Complete System of First Stage Equations}

Table 10 reports the estimates of the complete system of first stage equations as described by Equation (2). More specifically, Table 10 presents the first stage estimates of the empirical results in column (4) of Tables 2 and 3, respectively. ${ }^{36}$ As such, the coefficients of the interactions of Academic High Schools p.c. and Primary and Secondary Schools p.c. along the diagonal can be compared to the coefficients of the purely cross-sectional first stage coefficients in Column (4) of Table 1. Both the coefficients and standard errors of the system of first stage equations are very close to the ones for the single cross-section, in particular for the time periods close to Q4 2008, the date of the cross-section used for the estimations in Table 1. Moreover, the Shea Partial $R^{2}$

\footnotetext{
${ }^{35}$ Another share of this difference in total investments per school may be explained by the different sizes of academic high schools and primary and secondary schools pointed out in Appendix A.2.

${ }^{36}$ In Tables 2 and 3, we reduce the number of coefficients by interacting investments with indicator variables that equal one for all dates prior to the investment program (Q1 2007 to Q3 2008) and all dates after the end of the program (Q1 2011 to Q4 2013), respectively. For the years of the program (2009-2011), we estimated one coefficient for each year. Footnote 23 gives the formal statement of the relevant second stage. Table 10 applies the same procedure to the instruments of investments, Academic High Schools p.c. and Primary and Secondary Schools p.c. All the remaining variables are interacted with dummy variables for each quarterly date exactly as described by the models (1) and (2).
} 
Table 10: The Complete System of First Stage Equations

\begin{tabular}{|c|c|c|c|c|c|}
\hline \multirow[b]{3}{*}{$\begin{array}{l}\text { Academic High Schools p.c. } \\
\times \text {. 2007-Q3 } 2008\end{array}$} & \multicolumn{5}{|c|}{ Countercyclical Investments p.c. in $€ 100^{\prime} 000 \times$} \\
\hline & $\begin{array}{c}\text { 2007-Q3 } 2008 \\
\text { (1) }\end{array}$ & $\begin{array}{c}2009 \\
(2)\end{array}$ & $\begin{array}{c}2010 \\
(3)\end{array}$ & $\begin{array}{c}2011 \\
(4)\end{array}$ & $\begin{array}{l}2012-2013 \\
\quad(5)\end{array}$ \\
\hline & $\begin{array}{l}10.10^{* * *} \\
(2.97)\end{array}$ & $\begin{array}{c}0.00 \\
(0.01)\end{array}$ & $\begin{array}{r}-0.00 \\
(0.00)\end{array}$ & $\begin{array}{c}-0.00 \\
(0.01)\end{array}$ & $\begin{array}{c}-0.01 \\
(0.02)\end{array}$ \\
\hline$\times 2009$ & $\begin{array}{c}-0.00 \\
(0.04)\end{array}$ & $\begin{array}{l}10.09^{* * *} \\
(2.97)\end{array}$ & $\begin{array}{c}0.00 \\
(0.00)\end{array}$ & $\begin{array}{c}0.00 \\
(0.01)\end{array}$ & $\begin{array}{c}0.00 \\
(0.04)\end{array}$ \\
\hline$\times 2010$ & $\begin{array}{c}0.01 \\
(0.06)\end{array}$ & $\begin{array}{c}0.00 \\
(0.02)\end{array}$ & $\begin{array}{l}10.09^{* * *} \\
(2.97)\end{array}$ & $\begin{array}{c}-0.00 \\
(0.02)\end{array}$ & $\begin{array}{r}-0.01 \\
(0.06)\end{array}$ \\
\hline$\times 2011$ & $\begin{array}{c}0.01 \\
(0.09)\end{array}$ & $\begin{array}{c}0.00 \\
(0.03)\end{array}$ & $\begin{array}{r}-0.00 \\
(0.01)\end{array}$ & $\begin{array}{l}10.09^{* * *} \\
(2.96)\end{array}$ & $\begin{array}{c}-0.01 \\
(0.09)\end{array}$ \\
\hline$\times 2012-2013$ & $\begin{array}{c}0.21 \\
(0.21)\end{array}$ & $\begin{array}{c}0.06 \\
(0.07)\end{array}$ & $\begin{array}{r}-0.02 \\
(0.04)\end{array}$ & $\begin{array}{c}-0.07 \\
(0.08)\end{array}$ & $\begin{array}{l}9.88^{* * *} \\
(2.98)\end{array}$ \\
\hline $\begin{array}{l}\text { Primary \& Secondary Schoc } \\
\quad \times 2007-\text { Q3 } 2008\end{array}$ & $\begin{array}{l}1.52^{* *} \\
(0.64)\end{array}$ & $\begin{array}{r}-0.00 \\
(0.00)\end{array}$ & $\begin{array}{c}0.00 \\
(0.00)\end{array}$ & $\begin{array}{c}0.00 \\
(0.00)\end{array}$ & $\begin{array}{c}0.00 \\
(0.01)\end{array}$ \\
\hline$\times 2009$ & $\begin{array}{c}0.00 \\
(0.01)\end{array}$ & $\begin{array}{l}1.53^{* *} \\
(0.64)\end{array}$ & $\begin{array}{r}-0.00 \\
(0.00)\end{array}$ & $\begin{array}{c}-0.00 \\
(0.00)\end{array}$ & $\begin{array}{c}-0.00 \\
(0.01)\end{array}$ \\
\hline$\times 2010$ & $\begin{array}{c}0.00 \\
(0.02)\end{array}$ & $\begin{array}{c}0.00 \\
(0.01)\end{array}$ & $\begin{array}{l}1.53^{* *} \\
(0.64)\end{array}$ & $\begin{array}{c}-0.00 \\
(0.01)\end{array}$ & $\begin{array}{r}-0.00 \\
(0.02)\end{array}$ \\
\hline$\times 2011$ & $\begin{array}{c}0.01 \\
(0.03) \\
\end{array}$ & $\begin{array}{c}0.00 \\
(0.01) \\
\end{array}$ & $\begin{array}{c}-0.00 \\
(0.00)\end{array}$ & $\begin{array}{l}1.52^{* *} \\
(0.64)\end{array}$ & $\begin{array}{c}-0.01 \\
(0.03) \\
\end{array}$ \\
\hline$\times 2012-2013$ & $\begin{array}{c}0.05 \\
(0.06)\end{array}$ & $\begin{array}{c}0.01 \\
(0.02)\end{array}$ & $\begin{array}{r}-0.00 \\
(0.01)\end{array}$ & $\begin{array}{c}-0.01 \\
(0.02)\end{array}$ & $\begin{array}{c}1.48^{* *} \\
(0.64)\end{array}$ \\
\hline County Fixed Effects & yes & yes & yes & yes & yes \\
\hline Population Growth & yes & yes & yes & yes & yes \\
\hline Date Fixed Effects $\times$ & & & & & \\
\hline State $\times$ UrbanIndex & yes & yes & yes & yes & yes \\
\hline Emp. Shares by Educ. & yes & yes & yes & yes & yes \\
\hline School Age Population & yes & yes & yes & yes & yes \\
\hline Universities \& Hospitals & yes & yes & yes & yes & yes \\
\hline Kleibergen-Paap F & 1.98 & 1.98 & 1.98 & 1.98 & 1.98 \\
\hline Sanderson-Windmeijer F & 4.02 & 4.55 & 4.61 & 4.60 & 4.48 \\
\hline Shea Partial $\mathrm{R}^{2}$ & 0.07 & 0.07 & 0.07 & 0.07 & 0.07 \\
\hline Observations & 11200 & 11200 & 11200 & 11200 & 11200 \\
\hline
\end{tabular}

Notes. This table presents the first stage equations of column (4) of Tables 2 and 3. The dependent variable in column (1) is the sum of investments, normalized by the working-age population, interacted with an indicator that equals one for the observations between 2007 and Q3 2008. All the other dependent variables and interactions are defined accordingly. Academic High Schools p.c. is the number of high schools in a county which award the "Abitur." Primary and Secondary Schools p.c. is the number of primary schools and secondary schools. The remaining variables and statistics are described in Table 2. Standard errors clustered at the county level are in parentheses.

* $p<0.10,{ }^{* *} p<0.05,{ }^{* * *} p<0.01$. 51 
of the first stage equations in Table 10 and the cross-section are equal. These results are as expected, given that each of the first stage equations in Table 10 is, by design, identified almost exclusively from cross-sectional variation (only Population Growth varies over time, and all the remaining covariates are interacted with the full set of date dummies).

Testing for weak instruments in a setting with many endogenous variables and many instruments is at the frontier of research in theoretical econometrics. Table 10 presents, for each first stage equation, the F-statistic proposed by Sanderson and Windmeijer (2016). Their test for weak instruments (sketched by Angrist and Pischke 2009) is based on the application of the Frisch-Waugh-Lovell theorem to each first stage. In a first step, the testing procedure partials out, for one first stage equation the remaining endogenous variables (instrumented by the complete set of instruments) as well as all the exogenous covariates. In a second step, the resulting residuals are regressed on the instruments, and an F-test on the coefficients of the instruments is performed. This is done to assess whether the remaining explanatory power of the instruments is sufficient to identify the first stage equation under consideration. Applied to each first stage equation, the F-statistic proposed by Sanderson and Windmeijer hence allows to evaluate the relevance of the instruments for each endogenous variable separately.

The results in Table 10 show that the instruments are equally informative for each investment-period interaction. But the F-statistics are below the commonly chosen critical value of ten, potentially indicating that the instruments are weak. However, the Sanderson-Windmeijer F-statistic, which equals the Kleibergen-Paap F-statistic in the single endogenous regressor case displayed in Table 1, only drops because each additional interaction of $\boldsymbol{S} \boldsymbol{c h o o l} \boldsymbol{s}_{\boldsymbol{c}}$ is informative for only one endogenous variable and uninformative for all remaining endogenous variables (as illustrated by the statistically insignificant coefficients off the diagonal in Table 10). It is hence questionable whether the F-statistic is a good diagnostic for detecting weak instruments in the specific empirical model estimated here (see Angrist and Pischke, 2009, p. 215, for a similar point).

We conduct one further exercise to assess whether the estimates of the dynamic model described by (1) and (2) are potentially biased due to weak instruments. In Appendix C.3 we transform Equation(1) to a cross-sectional model that allows us to estimate the job years created by investments using only one endogenous variable and two instruments. This standard IV setup delivers first stage F-statistics at the same 
Figure 5: The Autocorrelation of Schools between 1995 and 2008 in West and East Germany

(a) Primary and Secondary Schools

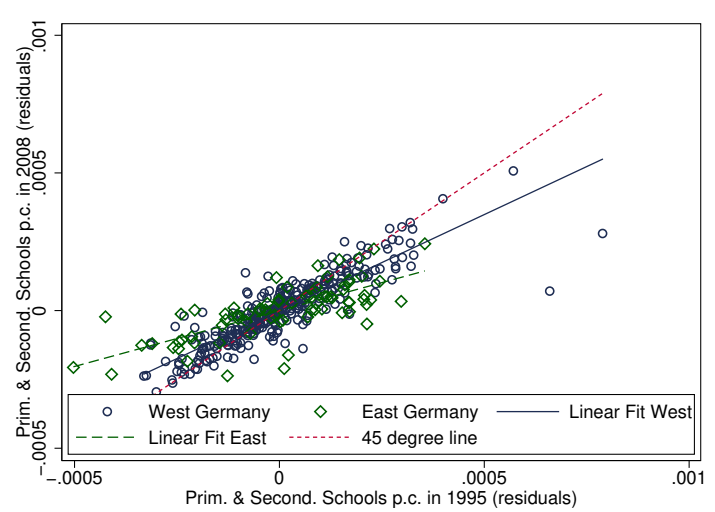

(b) Academic High Schools

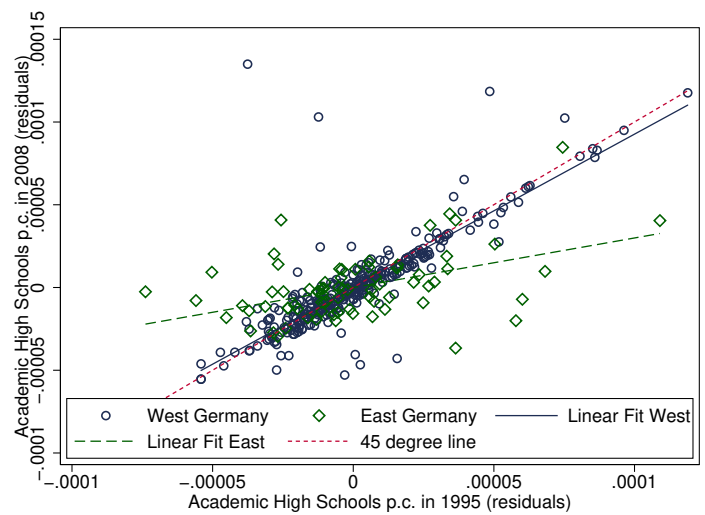

Notes. This figure displays, for each county, the number of schools (net of their state averages and separately for academic high schools and primary and secondary schools) in 2008 against the number of schools in 1995. Observations in the former West German states are indicated as circles, and their linear fit is given by the straight line. Observations in the former East German states are indicated by diamonds, and their linear fit is given by the dashed line.

level of the ones reported in Table 1, and the estimated job years / costs per job year as well as the corresponding standard errors are very close to the estimates from the main specification reported in Table 2. These results reinforce the notion that the crosssectional tests for weak instruments are appropriate to evaluate the relevance of the instruments in a specification like ours, in which the first stage is primarily identified from cross-sectional variation.

\section{B.3 The Persistence of the Number of Schools in West and East Germany}

Figure 5 plots the number of schools in 2008 against the number of schools in 1995 (the earliest date at which this data is available), separately for counties in the former West German states (displayed as circles) and in the former East German states (displayed as diamonds). In both years, schools are measured relative to their state averages. Clearly, the number of schools in the West is more persistent than in the East. This is particularly true for academic high schools, the stronger of the two instruments, where the observations in the West German counties are tightly clustered around the 45 degree line indicating a high persistence. In the East German counties, in contrast, the best linear fit of the observations is close to a horizontal line indicating a low persistence. 
This result may be due to the significant restructuring of the administration in the East German states in the wake of reunification. Due to the low persistence of the number of schools in the East German states as well as the accompanying renovations of the remaining infrastructure, the need for additional renovations via the stimulus program was most likely significantly lower in the East than in the West. The lower need for renovations in the East, in turn, may be the prime reason for not finding any employment effect for the sample of the East German counties in the robustness checks (Table 6).

\section{Appendix to Section 6: Results}

This section provides additional results regarding the robustness of the main empirical findings. Section C.1 presents evidence that stimulus investments from the federal government did not crowd out investments by counties and municipalities. Section C.2 shows that the estimated employment and unemployment effects do not change significantly when they are estimated relative to average employment or average unemployment between 2007 and 2008 instead of relative to Q4 2008. Section C.3 demonstrates that collapsing the empirical model (1) to a cross-sectional specification yields the same estimates of job years or reductions in unemployment years as the dynamic models in Tables 2 and 3 .

\section{C.1 The Limited Fungibility of Countercyclical Investments}

A common concern regarding the use of infrastructure investments as job creation programs is that federal investment grants merely replace investments of local layers of government. If this had been the case for the German investment program, the investments undertaken via the program would not constitute a spending increase, and our findings would be, by and large, spurious correlations.

To prevent a crowding out of local investments, the stimulus bill limited the fungibility of the stimulus funds. The bill required that projects could only receive funding if they were new and additional, meaning that they could not have been included in the budget of regional or state governments. Also, the states could only receive federal funds if their yearly investments exceeded 60 percent of the average yearly investments before the crisis.

In the following, we conduct a simple test to check whether the investment funds 
provided by the federal and the state governments crowded out investments of the counties and municipalities. To this end, we combine the data on countercyclical investments, for which we know where they were spent but not how they were budgeted, with yearly data on general investment grants received and on general investment expenditures from the balance sheets of the counties and municipalities. Specifically, we estimate the following two models:

$$
\begin{aligned}
& \text { Inv. Grants p. } c_{c, y}=\zeta_{\text {pre }} \text { Investments p.c. } ._{c} \times \mathbb{1}(y=2007)+ \\
& \zeta_{\text {during }} \text { Investments p.c.c } \times \mathbb{1}(y \in[2009,2011])+ \\
& \zeta_{\text {post }} \text { Investments p.c.c } \times \mathbb{1}(y \in[2012,2013])+ \\
& \text { CountyF } E_{c}+\epsilon_{c, y} \\
& \text { Inv. Expenditures p.c.c,y }=\eta_{\text {pre }} \text { Investments p.c. } \cdot_{c} \times \mathbb{1}(y=2007)+ \\
& \eta_{\text {during }} \text { Investments p.c.c } \times \mathbb{1}(y \in[2009,2011])+ \\
& \eta_{\text {post }} \text { Investments p.c.c } \times \mathbb{1}(y \in[2012,2013])+ \\
& \text { CountyF } E_{c}+\tilde{\epsilon}_{c, y} \text {, }
\end{aligned}
$$

where the index $y$ refers to years - the balance sheet data is published at yearly frequency-, and where $\epsilon_{c, y}$ and $\tilde{\epsilon}_{c, y}$ are the error terms. The difference $\eta_{\text {during }}-\zeta_{\text {during }}$ are the local investments expenditures in excess of investment grants per euro of stimulus investments within the counties' borders. If this difference is negative, it would be indicative of local crowding out of stimulus investments, as the average investment grants received due to the stimulus would be larger than the counties' average expenditures into stimulus projects. Conversely, if $\eta_{\text {during }}-\zeta_{\text {during }}$ would be positive, this would be indicative of crowding in.

Table 11 presents the estimates of the two models above. In columns (1) and (3), the covariate of interest is total countercyclical investments, which is the same variable as in the main part of the paper. In columns (2) and (4), the covariate of interest is the countercyclical investments into schools, as defined in Appendix B.1. The results show that higher total stimulus investments as well as higher investments in schools are associated both with higher investment grants and with higher investment expenditures of counties and municipalities. Compared to the respective values in 2008, an additional euro of total investments within a county is associated with an average yearly increase in investment grants of 7 cents, implying an increase of 21 cents over the three year period of the stimulus program. However, the average increase in investment expenditures is larger than the increase in investment grants. Here, one additional 
Table 11: The Correlation of Stimulus Investments with Total County Investment Expenditures

\begin{tabular}{|c|c|c|c|c|}
\hline \multirow[b]{2}{*}{ Investments (Indep. Var.): } & \multicolumn{2}{|c|}{ Investment Grants p.c. } & \multicolumn{2}{|c|}{ Investment Expenditures p.c. } \\
\hline & $\begin{array}{l}\text { in total } \\
(1)\end{array}$ & $\begin{array}{c}\text { into schools } \\
(2)\end{array}$ & $\begin{array}{c}\text { in total } \\
(3)\end{array}$ & $\begin{array}{l}\text { into schools } \\
(4)\end{array}$ \\
\hline Investments p.c. $\times 2007$ & $\begin{array}{c}0.01 \\
(0.01)\end{array}$ & $\begin{array}{c}0.00 \\
(0.02)\end{array}$ & $\begin{array}{c}-0.07^{* * *} \\
(0.02)\end{array}$ & $\begin{array}{c}-0.14^{* * *} \\
(0.03)\end{array}$ \\
\hline Investments p.c. $\times 2009-2011$ & $\begin{array}{l}0.07^{* * *} \\
(0.01)\end{array}$ & $\begin{array}{l}0.10^{* * *} \\
(0.02)\end{array}$ & $\begin{array}{l}0.13^{* * *} \\
(0.02)\end{array}$ & $\begin{array}{l}0.24^{* * *} \\
(0.03)\end{array}$ \\
\hline Investments p.c. $\times 2012-2013$ & $\begin{array}{c}-0.00 \\
(0.01)\end{array}$ & $\begin{array}{c}-0.02 \\
(0.02)\end{array}$ & $\begin{array}{c}-0.06^{* *} \\
(0.03)\end{array}$ & $\begin{array}{c}-0.13^{* *} \\
(0.05)\end{array}$ \\
\hline County Fixed Effects & yes & yes & yes & yes \\
\hline Observations & 2000 & 2000 & 2000 & 2000 \\
\hline
\end{tabular}

Notes. The dependent variable in columns (1) and (2), Investment Grants p.c., is the sum of investment grants to a county and all its municipalities from higher layers of government taken from the balance sheets of counties and municipalities. The dependent variable in columns (3) and (4), Investment Expenditures p.c., is the sum of all the investment expenditures of a county and its municipalities taken from the balance sheets. Both variables are normalized by the working-age population (as indicated by "p.c." for per capita). Investments p.c. are either, in columns (1) and (3), the sum of all countercyclical investments within a county (the variable of interest in the main text), or, in columns (2) and (4), the sum of all school related investments (as defined in Appendix B.1). Investments p.c. $\times 2007$ is the interaction of the relevant investment variable with an indicator that equals one in 2007. All the other interactions are defined accordingly; the baseline year is 2008. The sample includes all the counties for which the balance sheet data is available for both investment grants and expenditures and all the years between 2007 and 2013. Standard errors clustered at the county level are in parentheses.

${ }^{*} p<0.10,{ }^{* *} p<0.05,{ }^{* * *} p<0.01$.

euro of total investments is associated with an average yearly increase of 13 cents, or 39 cents over the period of the investment program. The point estimates hence imply a contribution of the counties and municipalities of 18 cents per euro spent on stimulus investments, which is larger than half of the 25 cents per euro of total investments that states, counties, and municipalities had to contribute according to the stimulus bill.

The same picture arises for investments into schools. Quantitatively, the investment grants and expenditures from the balance sheets are more strongly associated with investments in schools than with the spending on all the investment projects. A plausible reason for this finding is that schools are with few exceptions directly financed by the counties and municipalities, in contrast to some of the other investment targets of the stimulus program. 


\section{C.2 Dynamics Relative to Averages of Employment and Unemployment between Q1 2007 and Q4 2008}

In the main text, we estimate the employment gains and unemployment reductions of the investment program relative to Q4 2008, the last quarterly date before the program was active. Calculating the gains and reductions relative to a single date allows us to evaluate whether the instrumented investments are correlated with (un)employment dynamics before the crisis. This comes at the potential cost that (un)employment levels at the reference date may be (spuriously) correlated with the instruments, resulting in potentiallly misleading estimates.

To rule out this potential concern, this section estimates the (un)employment gains relative to average (un)employment during the years 2007 and 2008, the entire preprogram period in the data. Specifically, we slightly modify the empirical model underlying the main results in Tables 2 and 3 as follows

$$
\begin{aligned}
(\text { Un }) \text { Employment p. } c_{c, t}= & \sum_{Y=2009}^{2011} \beta_{Y} \text { Investment }_{c} \times \mathbb{1}(\mathrm{t} \in[\mathrm{Q} 1 \mathrm{Y}, \mathrm{Q} 4 \mathrm{Y}])+ \\
& \beta_{\text {post }} \text { Investments }_{c} \times \mathbb{1}(t \in[\mathrm{Q} 12012, \mathrm{Q} 42013])+\text { CountyF }_{c}+ \\
& \sum_{t \neq \mathrm{Q} 42008} \text { Date }_{t} \times \text { CountyCharacteristics }_{c} \boldsymbol{\Gamma}_{\boldsymbol{t}}+\psi \text { PopGrowt }_{c, t}+\tilde{\varepsilon}_{c, t} .
\end{aligned}
$$

The only difference to the model underlying the main results outlined in Footnote 23 is that the investment coefficient of the pre-program period vanishes.

Table 12 shows the results of estimating the model above with Employment p.c. as the dependent variable, Table 13 shows the results for Unemployment p.c. as the dependent variable. Across specifications, the employment gains are slightly smaller than the ones reported in Table 2, and the unemployment reductions are larger than the ones in Table 3 for the majority of the specifications. Overall, however, both the employment gains and unemployment reductions are of similar magnitudes as the corresponding estimates in the main text.

\section{C.3 The Estimated (Un)Employment Effects of Investments Using the Cross-Sectional Dimension of the Data}

In the main empirical model (1) we interact the cross-sectional data on investments across counties with indicator variables for the quarterly dates to estimate the dynamic 
Table 12: Effects of Investments on Employment Relative to Pre-Program Averages

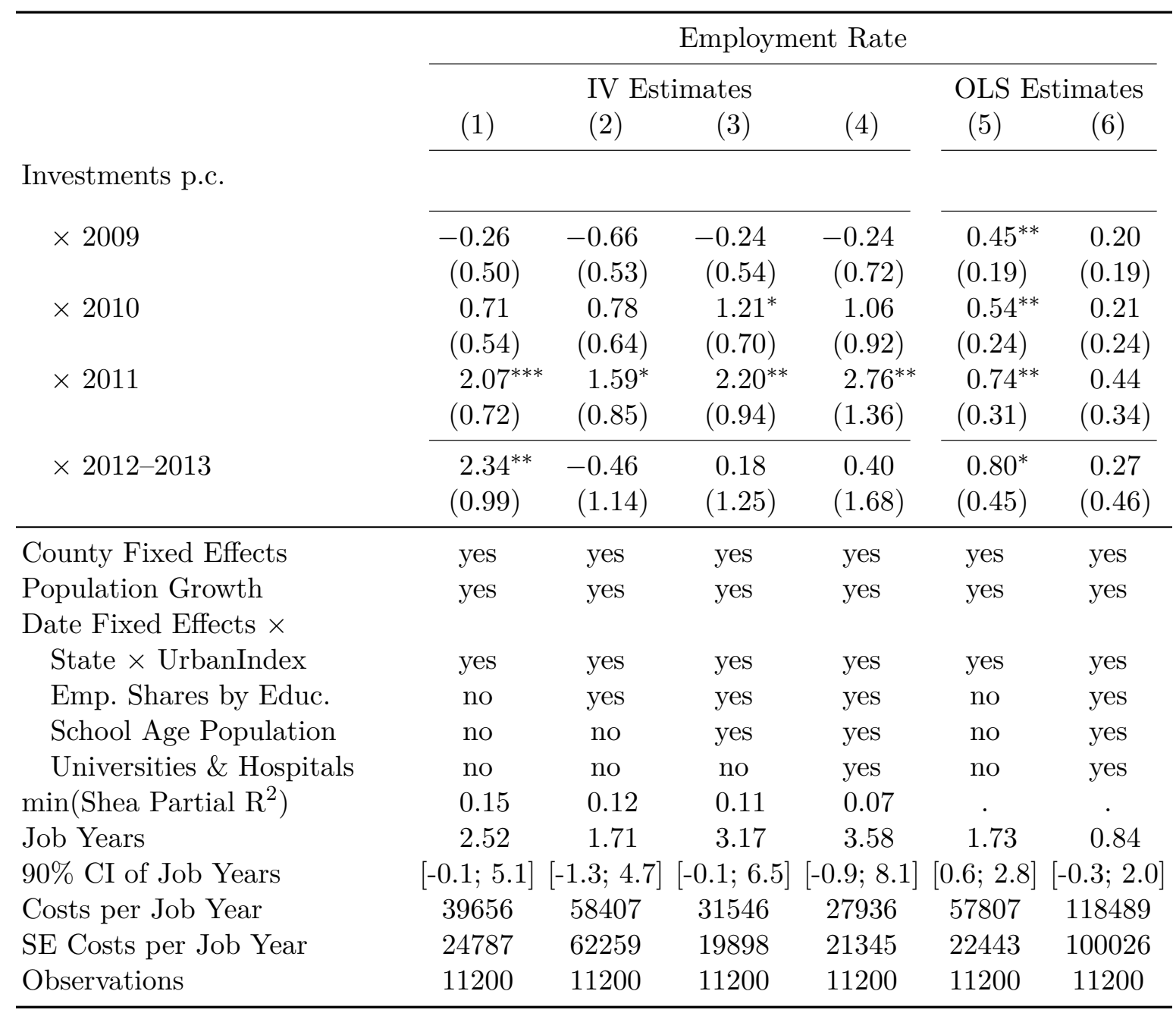

Notes. The dependent variable is the employment rate at each quarterly date between Q1 2007 and Q4 2013. Investments p.c. $\times 2009$ is the interaction of investments in $€ 100$ '000 with an indicator that equals one for all the observations in 2009. All the other interactions are defined accordingly; the baseline are the years 2007 and 2008. The horizontal lines between the estimates indicate the beginning and the end of the stimulus program. Population Growth is the ratio of the current workingage population and the working-age population in 2008. The following variables, measured in 2008, are interacted with the full set of date fixed effects: State $\times$ UrbanIndex (interactions of indicators for the states and the values of the urbanization index), Emp. Shares by Educ. (shares of employees with a college degree and with vocational training), School-Age Population, and Universities and Hospitals. Min(Shea Partial $R^{2}$ ) reports the minimum of the Shea $R^{2}$ of the excluded instruments - the date interactions of Academic High Schools p.c. and Primary and Secondary Schools p.c.- -among all the first stages (one for each interaction of Investments p.c.). The number of Job Years is the sum of the coefficients of Investments p.c. between 2009 and 2011. Costs per Job Year equal 100'000/Job Years. The confidence intervals of Job Years and the standard errors of Costs per Job Year are calculated via the Delta Method. Standard errors clustered at the county level are in parentheses.

${ }^{*} p<0.10,{ }^{* *} p<0.05,{ }^{* * *} p<0.01$. 
Table 13: Effects of Investments on Unemployment Relative to Pre-Program Averages

\begin{tabular}{|c|c|c|c|c|c|c|}
\hline \multirow[b]{4}{*}{ Investments p.c. } & \multicolumn{6}{|c|}{ Unemployment Rate } \\
\hline & \multicolumn{4}{|c|}{ IV Estimates } & \multicolumn{2}{|c|}{ OLS Estimates } \\
\hline & (1) & $(2)$ & $(3)$ & $(4)$ & $(5)$ & $(6)$ \\
\hline & & & & & & \\
\hline$\times 2009$ & $\begin{array}{c}0.02 \\
(0.56)\end{array}$ & $\begin{array}{c}-0.16 \\
(0.61)\end{array}$ & $\begin{array}{c}0.12 \\
(0.60)\end{array}$ & $\begin{array}{c}-0.44 \\
(0.85)\end{array}$ & $\begin{array}{c}-0.26 \\
(0.18)\end{array}$ & $\begin{array}{c}-0.22 \\
(0.20)\end{array}$ \\
\hline$\times 2010$ & $\begin{array}{c}-0.32 \\
(0.53)\end{array}$ & $\begin{array}{c}-1.00 \\
(0.64)\end{array}$ & $\begin{array}{c}-0.60 \\
(0.63)\end{array}$ & $\begin{array}{c}-1.30 \\
(0.88)\end{array}$ & $\begin{array}{c}-0.25 \\
(0.20)\end{array}$ & $\begin{array}{c}-0.27 \\
(0.22)\end{array}$ \\
\hline$\times 2011$ & $\begin{array}{r}-1.14^{*} \\
(0.61)\end{array}$ & $\begin{array}{c}-1.87^{* *} \\
(0.73)\end{array}$ & $\begin{array}{c}-1.46^{* *} \\
(0.72)\end{array}$ & $\begin{array}{c}-2.52^{* *} \\
(1.05)\end{array}$ & $\begin{array}{c}-0.26 \\
(0.23)\end{array}$ & $\begin{array}{c}-0.32 \\
(0.26)\end{array}$ \\
\hline$\times 2012-2013$ & $\begin{array}{c}-0.98 \\
(0.70)\end{array}$ & $\begin{array}{c}-2.00^{* *} \\
(0.84)\end{array}$ & $\begin{array}{r}-1.49^{*} \\
(0.83)\end{array}$ & $\begin{array}{c}-2.89^{* *} \\
(1.22)\end{array}$ & $\begin{array}{c}-0.22 \\
(0.27)\end{array}$ & $\begin{array}{c}-0.37 \\
(0.31)\end{array}$ \\
\hline County Fixed Effects & yes & yes & yes & yes & yes & yes \\
\hline Population Growth & yes & yes & yes & yes & yes & yes \\
\hline \multicolumn{7}{|l|}{ Date Fixed Effects $\times$} \\
\hline State $\times$ UrbanIndex & yes & yes & yes & yes & yes & yes \\
\hline Emp. Shares by Educ. & no & yes & yes & yes & no & yes \\
\hline School Age Population & no & no & yes & yes & no & yes \\
\hline Universities \& Hospitals & no & no & no & yes & no & yes \\
\hline $\min \left(\right.$ Shea Partial $\left.\mathrm{R}^{2}\right)$ & 0.15 & 0.12 & 0.11 & 0.07 & 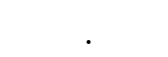 & . \\
\hline Job Years & 1.45 & 3.02 & 1.94 & 4.26 & 0.76 & 0.81 \\
\hline $90 \%$ CI of Job Years & {$[-1.1 ; 4.0]$} & {$[-0.0 ; 6.1]$} & {$[-1.0 ; 4.9]$} & {$[0.1 ; 8.5]$} & {$[-0.2 ; 1.7]$} & {$[-0.2 ; 1.8]$} \\
\hline Costs per Job Year & 68969 & 33089 & 51433 & 23460 & 130836 & 122771 \\
\hline SE Costs per Job Year & 74064 & 20196 & 47103 & 14072 & 96639 & 93883 \\
\hline Observations & 11200 & 11200 & 11200 & 11200 & 11200 & 11200 \\
\hline
\end{tabular}

Notes. The dependent variable is the unemployment rate at each quarterly date between Q1 2007 and Q4 2013. Investments p.c. $\times 2009$ is the interaction of investments in $€ 100$ '000 with an indicator that equals one for all the observations in 2009. All the other interactions are defined accordingly; the baseline are the years 2007 and 2008. The horizontal lines between the estimates indicate the beginning and the end of the stimulus program. Population Growth is the ratio of the current workingage population and the working-age population in 2008. The following variables, measured in 2008, are interacted with the full set of date fixed effects: State $\times$ UrbanIndex (interactions of indicators for the states and the values of the urbanization index), Emp. Shares by Educ. (shares of employees with a college degree and with vocational training), School-Age Population, and Universities and Hospitals. Min(Shea Partial $R^{2}$ ) reports the minimum of the Shea $R^{2}$ of the excluded instruments - the date interactions of Academic High Schools p.c. and Primary and Secondary Schools p.c.- -among all the first stages (one for each interaction of Investments p.c.). The number of Job Years is the sum of the coefficients of Investments p.c. between 2009 and 2011. Costs per Job Year equal 100'000/Job Years. The confidence intervals of Job Years and the standard errors of Costs per Job Year are calculated via the Delta Method. Standard errors clustered at the county level are in parentheses.

${ }^{*} p<0.10,{ }^{* *} p<0.05,{ }^{* * *} p<0.01$. 
effect of the countercyclical investment program. This strategy results in many endogenous variables. We instrument these endogenous variables with date interactions of the instruments, Academic High School p.c. and Primary and Secondary Schools p.c., which also vary predominantly along the cross-sectional dimension of the data. As pointed out in Appendix (B.2), the properties of IV models with many endogenous variables and many instruments are poorly understood. Also, every date interaction of the number of schools is uninformative for all but one of the endogenous variables so that the F-statistics of the excluded instruments in the first stage models in Table 10 at values that typically indicate weak instrument problems. This is despite the fact that the number of schools seems to be a sufficiently relevant instrument in the cross-section, as shown in Table 1.

However, we can also estimate the main statistics of interest from cross-sectional empirical specification similar to the one used, e.g., by Dupor and McCrory (2015). Starting with (1), we subtract Employmentp.c.c,t on both sides, multiply by $1 / 4$ and sum over all the quarterly dates between Q1 2009 and Q4 2011, the dates during which the stimulus program was active. Noting that in (1) we set all the coefficients of the date interactions to zero for the baseline date Q4 2008, this gives

$$
\begin{aligned}
& 1 / 4 \sum_{t=\mathrm{Q} 12009}^{\mathrm{Q} 4}\left(\text { Employment p.c. } \cdot \text { c,t }_{2011} \text { Employment p.c.c,Q4 2008 }\right)= \\
& \left(1 / 4 \sum_{t=\mathrm{Q} 12009}^{\mathrm{Q} 42011} \beta_{t}\right) \text { Investments p.c. } \cdot \text { + CountyF } E_{c}+ \\
& \text { CountyCharacteristics, }\left(1 / 4 \sum_{t=\mathrm{Q} 12009}^{\mathrm{Q} 42011} \Gamma_{\boldsymbol{t}}\right)+ \\
& \left.1 / 4 \psi \sum_{t=\mathrm{Q} 12009}^{\mathrm{Q} 4} 2011 \text { PopGrowth } \text { }_{c, t}-\text { PopGrowt }_{c, \mathrm{Q} 42008}\right)+ \\
& 1 / 4 \sum_{t=\mathrm{Q} 12009}^{\mathrm{Q} 4} 2011
\end{aligned}
$$

Note that (3) is a cross-sectional model, as we sum across dates. Also, the coefficient of Investments p.c., 1/4 $\sum_{t=\mathrm{Q} 12009}^{\mathrm{Q} 42011} \beta_{t}$, directly gives the number of job years created by the program, which is the main statistics of interest reported throughout the main text. Estimating (3) thus recovers the statistic of interest with only a single endogenous variable, for which we can instrument by the cross-section of the number of schools. 
The advantage of restating the empirical model in terms of (3) is that we can use all the standard results regarding the estimation of IV models with a single endogenous variable. The disadvantage is that the estimates of (3) are uninformative about the dynamics of the employment effects.

Table 14 reports the estimates of (3), and Table 15 reports the estimates for the variant of (3) in which the dependent variable is the compound of the unemployment differences instead of the employment differences. The coefficients of Investment p.c. estimated via IV and their 90 percent confidence intervals are very close to the job year estimates from the main specifications in Tables 2 and $3 .{ }^{37}$ As with the panel model, the IV estimates from the cross-sectional model thus imply that the investment program led to substantial gains in employment and sizable reductions in unemployment. The OLS estimates from the cross-sectional specification, in contrast, are weakly smaller their counterparts in the main text. These estimates imply that the investment program had both statistically and economically irrelevant effects on (un)employment. Finally, the Kleibergen-Paap F-statistics of the excluded instruments are above the common critical value of ten indicating that the instruments are relevant.

\footnotetext{
${ }^{37}$ With unemployment as the dependent variable, the results are virtually identical in the two most demanding specifications.
} 
Table 14: Employment Effects from a Cross-Sectional Specification

\begin{tabular}{|c|c|c|c|c|c|c|}
\hline & $1 / 4 \sum_{t=}^{\mathrm{Q}}$ & $\begin{array}{l}\mathrm{Q} 42011 \\
t=\mathrm{Q} 12009\end{array}$ & Empl. Ra & $\mathrm{te}_{t}-\mathrm{Emp}$ & pl. $\operatorname{Rate}_{\mathrm{Q}}$ & $242008)$ \\
\hline & & IV Esti & imates & & OLS Es & stimates \\
\hline & (1) & $(2)$ & $(3)$ & (4) & $(5)$ & $(6)$ \\
\hline Investments p.c. & $2.80^{* *}$ & $3.41^{* *}$ & $4.04^{* *}$ & $3.82^{*}$ & 0.71 & -0.06 \\
\hline & $(1.32)$ & $(1.58)$ & $(1.72)$ & $(2.27)$ & $(0.61)$ & $(0.60)$ \\
\hline Population Growth & $0.40^{* * *}$ & $0.39^{* * *}$ & $0.37^{* * *}$ & $0.39^{* * *}$ & $0.42^{* * *}$ & $0.42^{* * *}$ \\
\hline & $(0.03)$ & $(0.03)$ & $(0.04)$ & $(0.04)$ & $(0.03)$ & $(0.03)$ \\
\hline Empl. Share w College /100 & & $9.55^{* * *}$ & $10.69^{* * *}$ & $13.31^{* * *}$ & & $14.83^{* * *}$ \\
\hline & & $(3.47)$ & $(3.65)$ & $(3.50)$ & & $(3.07)$ \\
\hline Empl. Share w Vocational Tr. /100 & & $6.58^{* *}$ & $4.63^{*}$ & $5.85^{* *}$ & & $5.83^{* *}$ \\
\hline & & $(2.70)$ & $(2.79)$ & $(2.85)$ & & $(2.79)$ \\
\hline Share School-Age Pop /100 & & & $11.52^{*}$ & 8.28 & & 5.01 \\
\hline & & & $(6.67)$ & $(6.44)$ & & $(5.85)$ \\
\hline Universities p.c. & & & & -412.83 & & -71.73 \\
\hline & & & & $(300.45)$ & & $(193.29)$ \\
\hline Hospitals p.c. & & & & 50.46 & & $83.92^{* * *}$ \\
\hline & & & & $(31.47)$ & & $(23.00)$ \\
\hline State $\times$ UrbanIndex FE & yes & yes & yes & yes & yes & yes \\
\hline Kleibergen-Paap F & 22.62 & 21.09 & 18.30 & 10.27 & . & . \\
\hline Shea Partial $\mathrm{R}^{2}$ & 0.16 & 0.13 & 0.11 & 0.07 & . & . \\
\hline Job Years & 2.80 & 3.41 & 4.04 & 3.82 & 0.71 & -0.06 \\
\hline $90 \%$ CI of Job Years & {$[0.6 ; 5.0]$} & {$[0.8 ; 6.0]$} & {$[1.2 ; 6.9]$} & {$[0.1 ; 7.6][$} & {$[-0.3 ; 1.7]$} & {$[-1.0 ; 0.9]$} \\
\hline Costs per Job Year & 35703 & 29362 & 24735 & 26199 & 141661 & -1674511 \\
\hline SE Costs per Job Year & 16876 & 13597 & 10516 & 15584 & 121879 & 16700532 \\
\hline Observations & 400 & 400 & 400 & 400 & 400 & 400 \\
\hline
\end{tabular}

Notes. The dependent variable is the sum of the employment differences relative to Q4 2008 across all the quarterly dates during the program period. Investments p.c. in $€ 100$ '000 is the sum of investments normalized by the working-age population (indicated by "p.c." for "per capita") over the years 2009 to 2011. Population Growth is the sum of the yearly growth of the working-age population relative to 2008 given by $1 / 4 \sum_{t=\mathrm{Q} 12009}^{\mathrm{Q} 42011}$ (WorkingAgePop $, t, W_{\text {orking AgePop }}, 2008-1$ ). Empl. Share $w$ College and Empl. Share w Vocational Tr. are the share of employees with a college degree and vocational training, respectively. Share School-Age Pop is the number of individuals between 6 and 18 years of age as a fraction of the working-age population. Universities p.c. and Hospitals p.c. are the number of universities and hospitals. State $\times$ UrbanIndex FE are fixed effects for the interaction of indicator variables for the German states and for the values of a four-point urbanization index. Academic High Schools p.c. and Primary and Secondary Schools p.c. are the excluded instruments for Investments p.c. underlying the Kleibergen-Paap F statistic and the Shea Partial $R^{2}$. The sample is the cross-section of counties as measured in Q4 2008. Robust standard errors are in parentheses.

${ }^{*} p<0.10,{ }^{* *} p<0.05,{ }^{* * *} p<0.01$. 
Table 15: Unemployment Effects from a Cross-Sectional Specification

\begin{tabular}{|c|c|c|c|c|c|c|}
\hline & \multicolumn{6}{|c|}{$1 / 4 \sum_{t=\mathrm{Q} 12009}^{\mathrm{Q} 42011}($ Unem. Rate $t-$ Unem. Rate Q 42008$)$} \\
\hline & \multirow{2}{*}{\multicolumn{3}{|c|}{ IV Estimates }} & \multirow[b]{2}{*}{$(4)$} & \multicolumn{2}{|c|}{ OLS Estimates } \\
\hline & & & & & $(5)$ & (6) \\
\hline Investments p.c. & $\begin{array}{c}-0.37 \\
(1.42)\end{array}$ & $\begin{array}{c}-1.91 \\
(1.56)\end{array}$ & $\begin{array}{r}-1.88 \\
(1.64)\end{array}$ & $\begin{array}{l}-2.95 \\
(2.26)\end{array}$ & $\begin{array}{c}-0.25 \\
(0.62)\end{array}$ & $\begin{array}{c}-0.10 \\
(0.73)\end{array}$ \\
\hline Population Growth & $\begin{array}{l}0.07^{* * *} \\
(0.03)\end{array}$ & $\begin{array}{l}0.08^{* * *} \\
(0.03)\end{array}$ & $\begin{array}{c}0.07^{* *} \\
(0.03)\end{array}$ & $\begin{array}{c}0.08^{* *} \\
(0.03)\end{array}$ & $\begin{array}{l}0.07^{* * *} \\
(0.02)\end{array}$ & $\begin{array}{r}0.05^{*} \\
(0.03)\end{array}$ \\
\hline Empl. Share w College /100 & & $\begin{array}{r}-4.96 \\
(3.31)\end{array}$ & $\begin{array}{r}-4.21 \\
(3.23)\end{array}$ & $\begin{array}{c}-4.21 \\
(3.17)\end{array}$ & & $\begin{array}{r}-5.33^{*} \\
(2.96)\end{array}$ \\
\hline Empl. Share w Vocational Tr. /100 & & $\begin{array}{c}-5.69^{* *} \\
(2.60)\end{array}$ & $\begin{array}{c}-6.63^{* *} \\
(2.68)\end{array}$ & $\begin{array}{c}-6.32^{* *} \\
(2.71)\end{array}$ & & $\begin{array}{c}-6.30^{* *} \\
(2.63)\end{array}$ \\
\hline Share School-Age Pop /100 & & & $\begin{array}{c}5.05 \\
(5.06)\end{array}$ & $\begin{array}{c}6.47 \\
(4.96)\end{array}$ & & $\begin{array}{c}8.88^{*} \\
(4.61)\end{array}$ \\
\hline Universities p.c. & & & & $\begin{array}{c}287.93 \\
(266.20)\end{array}$ & & $\begin{array}{c}36.71 \\
(205.56)\end{array}$ \\
\hline Hospitals p.c. & & & & $\begin{array}{c}51.15 \\
(32.51)\end{array}$ & & $\begin{array}{c}26.51 \\
(24.66)\end{array}$ \\
\hline State $\times$ UrbanIndex FE & yes & yes & yes & yes & yes & yes \\
\hline Kleibergen-Paap F & 22.62 & 21.09 & 18.30 & 10.27 & . & . \\
\hline Shea Partial $\mathrm{R}^{2}$ & 0.16 & 0.13 & 0.11 & 0.07 & . & . \\
\hline Job Years & 0.37 & 1.91 & 1.88 & 2.95 & 0.25 & 0.10 \\
\hline $90 \%$ CI of Job Years & {$[-2.0 ; 2.7][-$} & $-0.7 ; 4.5][-$ & $-0.8 ; 4.6]$ & {$[-0.8 ; 6.7]$} & {$[-0.8 ; 1.3][$} & {$[-1.1 ; 1.3]$} \\
\hline Costs per Job Year & -272630 & -52463 & -53217 & -33872 & -397400 & -1030545 \\
\hline SE Costs per Job Year & 1055917 & 42816 & 46350 & 25959 & 984706 & 7713300 \\
\hline Observations & 400 & 400 & 400 & 400 & 400 & 400 \\
\hline
\end{tabular}

Notes. The dependent variable is the sum of the unemployment differences relative to Q4 2008 across all the quarterly dates during the program period. Investments p.c. in $€ 100$ '000 is the sum of investments normalized by the working-age population (indicated by "p.c." for "per capita") over the years 2009 to 2011. Population Growth is the sum of the yearly growth of the working-age population relative to 2008 given by $1 / 4 \sum_{t=\mathrm{Q} 12009}^{\mathrm{Q} 42011}$ (WorkingAgePop,$t /$ WorkingAgePop p $_{c, 2008}-1$ ). Empl. Share $w$ College and Empl. Share $w$ Vocational Tr. are the share of employees with a college degree and vocational training, respectively. Share School-Age Pop is the number of individuals between 6 and 18 years of age as a fraction of the working-age population. Universities p.c. and Hospitals p.c. are the number of universities and hospitals. State $\times$ UrbanIndex FE are fixed effects for the interaction of indicator variables for the German states and for the values of a four-point urbanization index. Academic High Schools p.c. and Primary and Secondary Schools p.c. are the excluded instruments for Investments p.c. underlying the Kleibergen-Paap F statistic and the Shea Partial $R^{2}$. The sample is the cross-section of counties as measured in Q4 2008. Robust standard errors are in parentheses.

${ }^{*} p<0.10,{ }^{* *} p<0.05,{ }^{* * *} p<0.01$. 